\title{
Conductive Polymers and Their Nanocomposites as Adsorbents in Environmental Applications
}

\author{
Mohammad Ilyas Khan ${ }^{1, *(\mathbb{C})}$, Mohammed Khaloufa Almesfer ${ }^{1}$, Abubakr Elkhaleefa ${ }^{1}{ }^{\mathbb{C}}$, Ihab Shigidi ${ }^{1}{ }^{\circledR}$, \\ Mohammed Zubair Shamim ${ }^{2}$, Ismat H. Ali ${ }^{3}$ and Mohammad Rehan ${ }^{4}$ (D) \\ 1 Department of Chemical Engineering, College of Engineering, King Khalid University, \\ Abha 62529, Saudi Arabia; almesfer@kku.edu.sa (M.K.A.); amelkhalee@kku.edu.sa (A.E.); \\ etaha@kku.edu.sa (I.S.) \\ 2 Department of Electrical Engineering, College of Engineering, King Khalid University, \\ Abha 62529, Saudi Arabia; mzmohammad@kku.edu.sa \\ 3 Department of Chemistry, College of Science, King Khalid University, Abha 62529, Saudi Arabia; \\ ismathassanali@gmail.com \\ 4 Centre of Excellence in Environmental Studies, King Abdulaziz University, Jeddah 21577, Saudi Arabia; \\ dr.mohammad_rehan@yahoo.co.uk \\ * Correspondence: mkaan@kku.edu.sa
}

check for updates

Citation: Khan, M.I.; Almesfer, M.K.; Elkhaleefa, A.; Shigidi, I.; Shamim, M.Z.; Ali, I.H.; Rehan, M. Conductive Polymers and Their Nanocomposites as Adsorbents in Environmental Applications. Polymers 2021, 13, 3810. https://doi.org/10.3390/ polym 13213810

Academic Editors: Ali Gooneie and Clemens Holzer

Received: 14 October 2021

Accepted: 29 October 2021

Published: 4 November 2021

Publisher's Note: MDPI stays neutral with regard to jurisdictional claims in published maps and institutional affiliations.

Copyright: (c) 2021 by the authors. Licensee MDPI, Basel, Switzerland. This article is an open access article distributed under the terms and conditions of the Creative Commons Attribution (CC BY) license (https:// creativecommons.org/licenses/by/ $4.0 /)$.

\begin{abstract}
Proper treatment and disposal of industrial pollutants of all kinds are a global issue that presents significant techno-economical challenges. The presence of pollutants such as heavy metal ions (HMIs) and organic dyes (ODs) in wastewater is considered a significant problem owing to their carcinogenic and toxic nature. Additionally, industrial gaseous pollutants (GPs) are considered to be harmful to human health and may cause various environmental issues such as global warming, acid rain, smog and air pollution, etc. Conductive polymer-based nanomaterials have gained significant interest in recent years, compared with ceramics and metal-based nanomaterials. The objective of this review is to provide detailed insights into different conductive polymers (CPs) and their nanocomposites that are used as adsorbents for environmental remediation applications. The dominant types of CPs that are being used as adsorbent materials include polyaniline (PANI), polypyrrole (Ppy), and polythiophene (PTh). The various adsorption mechanisms proposed for the removal of ODs, HMIs, and other GPs by the different CPs are presented, together with their maximum adsorption capacities, experimental conditions, adsorption, and kinetic models reported.
\end{abstract}

Keywords: conductive polymers; nanocomposites; adsorption; environmental remediation; heavy metal ions; organic dyes; gaseous pollutants

\section{Introduction}

Industrialization, human development, and socio-economic activities are known to have led to the destruction and deterioration of the environment and have significantly affected human health. For example, the release of many different types of organic, inorganic, and gaseous pollutants into the environment and their subsequent penetration and accumulation in the food chain can be a significant threat to the environment and to human health [1]. It is well known that quite a significant portion of diseases and deaths are caused by consuming contaminated water and other polluted environmental issues in developing countries [2]. Among the inorganic contaminants, heavy metal ions (HMIs) are known to be the primary environmental contaminants [3]. The main sources of HMIs are metal processing and finishing industries [4], battery and electroplating industries, tanneries, glass and ceramic industries, as well as petroleum refining and mining industries [5,6]. Organic pollutants (OPs) vary in nature and have different environmental effects. Some organic pollutants are considered more toxic and harmful, compared with others. Organic dyes (ODs), primarily from textile industries, paper and pulp manufacturing, 
leather processing, food processing, pharmaceutical, and paints and coatings industries, are the main sources of contamination of wastewater [7,8]. Among gaseous pollutants (GPs), carbon dioxide $\left(\mathrm{CO}_{2}\right)$, also known as the greenhouse gas, is known to be associated with many industries such as power plants [9], petrochemical industries, hydrogen, and cement manufacturing plants [10], and is suspected to be the primary pollutant responsible for ozone layer degradation and subsequently for global warming.

In order to minimize the number of such pollutants and to meet the environmental standards and regulations, various treatment techniques have been reported in the literature, which are summarized in Figure 1. Among these, adsorption is known to be more practical, adaptable, feasible, efficient, and environmentally friendly, compared with the other available techniques.

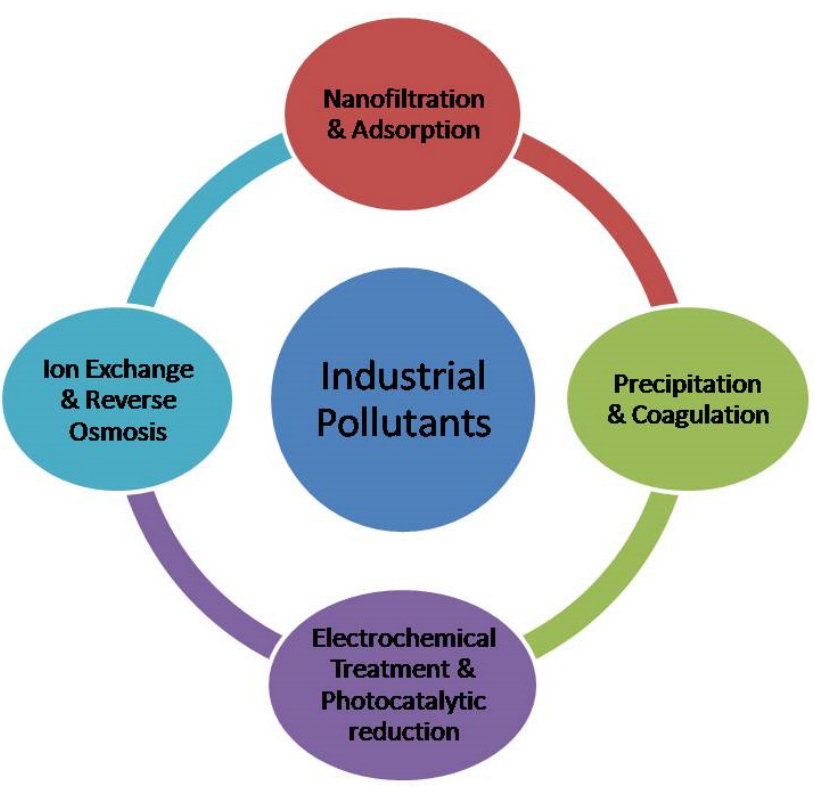

Figure 1. Various available treatment techniques for industrial pollutants.

Conductive polymers (CPs) are well known for their outstanding characteristics. CPs consist of conjugated $\pi$-bonds and offer unique electrical, optical, and physical properties. Some of the most common types of conductive polymers are listed in Table 1 [11]. Conductive polymers and their nanocomposites have gained tremendous popularity in recent years as being widely used in diverse fields of research and innovations. Their potential use as biosensors [12,13], gas sensors [14], and corrosion inhibitors in different environments [15-17], as well as in biomedical applications [18-21], or as adsorbents for the adsorption of various environmental pollutants [22], is widely anticipated and frequently reported in the literature.

There is no single and comprehensive review that is solely dedicated to the applications and utilization of conductive polymers for environmental remediation. The only review article that provides deeper insights into the useful applications of conductive polymers is presented by [22], which contains a section that deals with environmental remediation but is not exclusive. Aside from this review article, another review by [23] has highlighted the application of conductive polymers in water treatment. There are various other reviews but are mostly concerned with specific conductive polymer and its composites. The objective of the current review is to combine recent developments of different conductive polymers (such as polypyrrole, polyaniline, and polythiophene) and their nanocomposites in environmental remediation in one comprehensive article. This review also sheds light on the various reported aspects of CPs as adsorbents for heavy metal removal, maximum adsorption capacities, adsorption mechanisms, adsorption, and kinetic models. 
Table 1. Some conductive polymers and their chemical structures, Adapted from Ref. [6].

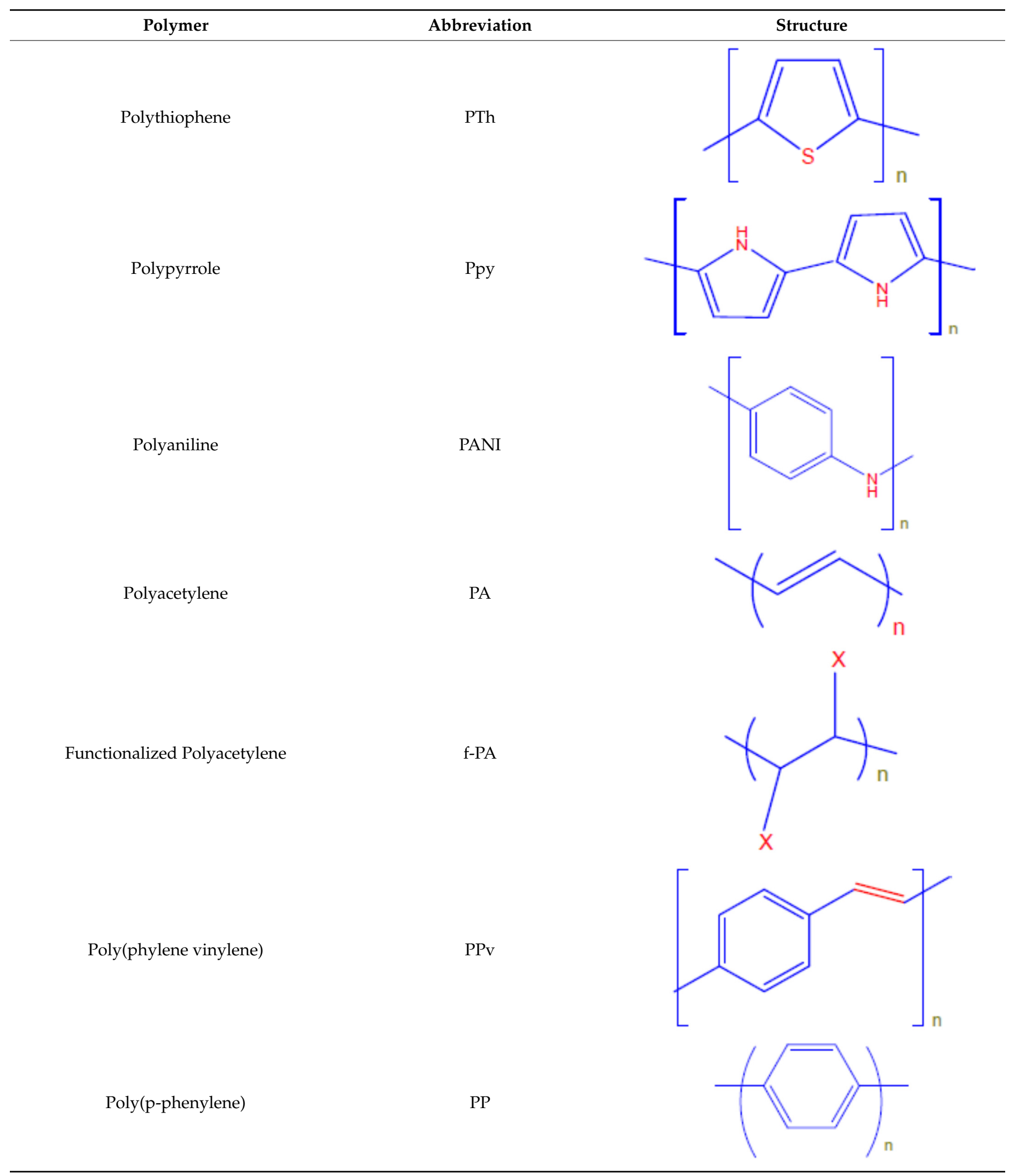




\section{Conductive Polymers as Adsorbents}

Conductive polymers and their nanocomposites as adsorbent materials have been shown to be effective and efficient in environmental remediation applications. This is most likely due to their interesting redox characteristics especially PANI [24], as well as other physical and chemical properties. The sorption characteristics of these adsorbents strongly depend on the solution $\mathrm{pH}$, initial concentration, contact time, adsorbent dosage, and temperature, as well as on the operating pressure in the case of gaseous pollutants removal. Section 2.1 of this article deals with polyaniline and its composites adsorbents for heavy metal ions, organic and pharmaceutical pollutants, organic dyes, and gaseous pollutants removal. Section 2.2 is dedicated to polypyrrole and its composites for heavy metal ions, organic dyes, and gaseous pollutants removal, while Section 2.3 deals with polythiophene and other conductive polymers and their derivatives as adsorbents for environmental remediation applications.

\subsection{PANI and PANI-Based Composite Adsorbents for the Removal of Heavy Metal Ions (HMIs)}

The various polyaniline-based adsorbents are discussed here, which as divided into HMIs and OPs. Removal of various heavy metals ions and organic dyes by polyaniline and its derivatives is presented in a recent review by [25]. Heavy metal ions (HMIs) removed by polyaniline-based nanocomposites include the removal of $\mathrm{Pb}$ (II) ions by polyaniline-modified multiwalled carbon nanotubes [26] under ambient conditions. It was concluded that due to the high affinity of amine and imine functional groups of $\mathrm{PANI}$ toward $\mathrm{Pb}$ (II) ions, the PANI modification significantly improved the adsorption capacity. Polyaniline synthesized on jute fiber surfaces for $\mathrm{Cr}$ (VI) removal was reported by [27]. At the optimum experimental conditions ( $\mathrm{pH} 3$ and temperature of $20{ }^{\circ} \mathrm{C}$ ), a maximum monolayer adsorption capacity of $62.9 \mathrm{mg} / \mathrm{g}$ was observed. It was reported that the total chromium adsorption decreased with increasing temperature, suggesting an exothermic nature of the chromium adsorption process. Additionally, utilization of polyaniline-coated polyacrylonitrile fiber mats for Cr (VI) removal was reported by [28], which concluded that PANI/PAN composite exhibited superior removal capabilities for $\mathrm{Cr}(\mathrm{VI})$. The maximum adsorption capacity was observed to increase with increasing temperature, which is suggestive of the endothermic nature of the adsorption process. In another research, $\mathrm{Cr}$ (VI) removal by polyaniline-coated carbon fiber fabric, cellulosepolyaniline composites was reported by [29]. They concluded that the introduction of PANI to their substrates improved both the adsorption rates and adsorption capacities. They reported that since the pseudo-second-order kinetic model fits well the experimental data, the adsorption process is physical adsorption in nature. The use of PANI-based adsorbents for the removal of $\mathrm{Cr}(\mathrm{VI})$ was extensively reported by [30].

The use of sodium alginate-polyaniline nanofibers for $\mathrm{Cr}(\mathrm{VI})$ ions adsorption was reported by [31] and observed that electrostatic interactions between the sodium alginatepolyaniline nanofibers and $\mathrm{Cr}(\mathrm{VI})$ were involved in the adsorption process. A maximum adsorption capacity of $73.34 \mathrm{mg} / \mathrm{g}$ was deduced from the Langmuir isotherm plots at $30{ }^{\circ} \mathrm{C}$ and the pseudo-second-order model fitted well the experimental data. Furthermore, the removal of $\mathrm{Hg}$ (II) from aqueous media was reported by [32], using polyaniline nanocomposite coated on rice husk ash. The removal of resorcinol from an aqueous solution was reported by [33], using SBA-15/polyaniline mesoporous composites. Polyaniline nanofibers assembled on alginate microspheres are used for the removal of $\mathrm{Pb}$ (II) and $\mathrm{Cu}$ (II) ions from aqueous media [34]. Cadmium metal ions Cd (II) removal from aqueous solution was reported by [35], using polyaniline-coated sawdust and $\mathrm{Pb}$ (II) and Cd (II) ions using polyaniline grafted chitosan [36]. The use of PANI-clay hybrid materials for the removal of $\mathrm{Cu}$ (II) was reported by [37]. Additionally, removal of arsenic (III) ions by magnetic polyaniline doped-strontium titanium nanocomposites adsorbent were reported by [38]. The maximum adsorption capacity was found to be $67.11 \mathrm{mg} / \mathrm{g}$ from the Langmuir isotherm model, and the nature of the adsorption process of arsenic (III) ions was found to be exothermic and physisorption deduced from the thermodynamic studies. The various 
adsorption mechanisms proposed for heavy metal ions removal are shown in Figure 2a,b, while a list of PANI and PANI-based adsorbents dealing with heavy metals ions removal under different experimental conditions are tabulated in Table 2.

(a)

(1) Electrostatic interaction or Anion-exchange

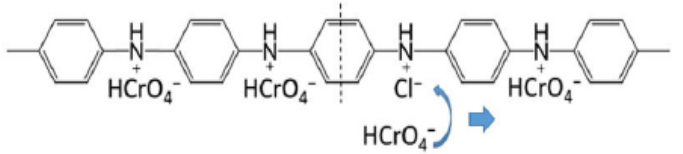

(2) Reduction<smiles>[3H]N=C1C=CC(=NC=C2CCCCC2)CC1</smiles><smiles>c1ccccc1</smiles>

(3) Chelation adsorption

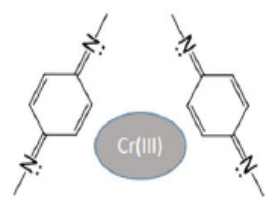

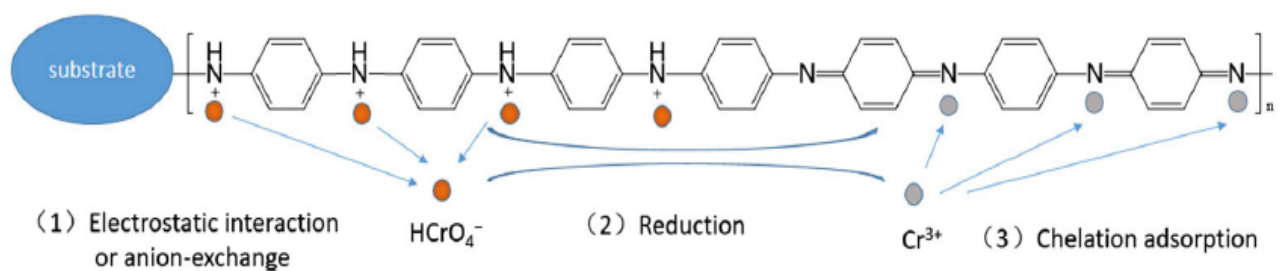

(b)

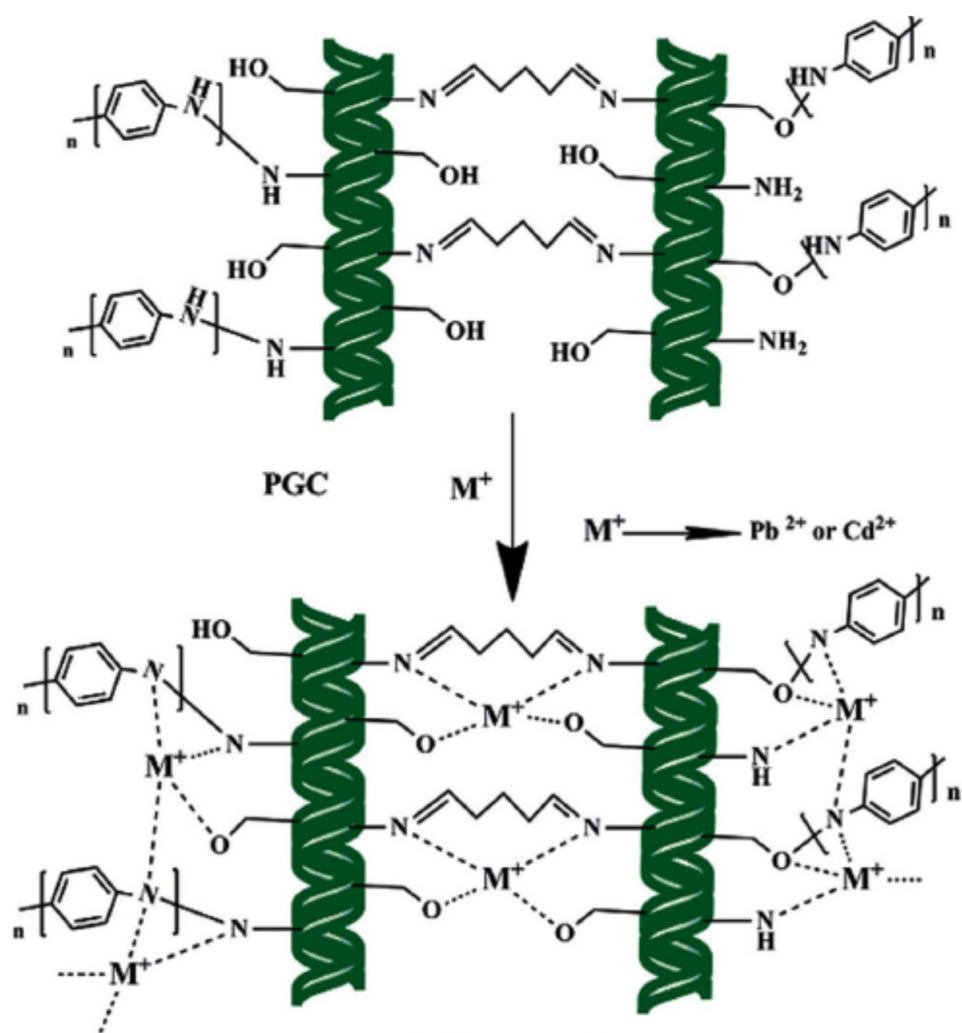

Metal loaded PGC

Figure 2. (a) Mechanism of chromium removal by PANI and PANI-based composites. Reprinted with permission from Ref. [30]. Copyright 2018 Springer Nature. (b) Proposed mechanism for the adsorption of $\mathrm{Pb}$ and $\mathrm{Cd}$ onto PANIGCS. Reprinted with permission from Ref. [25]. Copyright 2015 Elsevier. 
Table 2. PANI-based adsorbents for the removal of HMIs PANI-based adsorbents for the removal of HMIs.

\begin{tabular}{|c|c|c|c|c|c|}
\hline Adsorbent & Adsorbate & $\mathrm{pH}$ & $\begin{array}{c}\text { Temperature } \\
\left({ }^{\circ} \mathrm{C}\right)\end{array}$ & $\underset{(\mathrm{mg} / \mathrm{g})}{\mathrm{q}_{\max }}$ & Ref. \\
\hline PANI-JF & $\mathrm{Cr}(\mathrm{VI})$ & 3 & 40 & 62.89 & [27] \\
\hline PANI/CA composite & $\begin{array}{l}\mathrm{Cu}^{+2} \\
\mathrm{~Pb}^{+2}\end{array}$ & 6 & NA & $\begin{array}{c}67.95 \\
251.44\end{array}$ & {$[34]$} \\
\hline PANI-PGC & $\begin{array}{l}\mathrm{Pb}^{+2} \\
\mathrm{Cd}^{+2}\end{array}$ & 6 & 30 & $\begin{array}{l}16.07 \\
14.33\end{array}$ & [36] \\
\hline PANI/Clay & $\mathrm{Cu}^{+2}$ & 6 & 25 & 22.77 & [37] \\
\hline PANI-PS & $\mathrm{Pb}^{+2}$ & $2-6$ & NA & NA & [39] \\
\hline PANI-Chi composite & $\mathrm{Cr}(\mathrm{VI})$ & 3 & 45 & 1.01 & [40] \\
\hline PANI-BC mat & $\mathrm{Cr}(\mathrm{VI})$ & $1-2$ & NA & NA & [41] \\
\hline P-PANi-MMT & $\mathrm{Cu}^{+2}$ & 5 & NA & 87 & [42] \\
\hline $\begin{array}{c}\text { PANI-PVDF-HFP } \\
\text { nanofibrous }\end{array}$ & $\mathrm{Cr}(\mathrm{VI})$ & 4.5 & NA & 15.08 & [43] \\
\hline PANI and PANI-G10 & $\mathrm{Cr}(\mathrm{VI})$ & 6.5 & 30 & $\begin{array}{l}136, \\
192\end{array}$ & {$[44]$} \\
\hline
\end{tabular}

2.2. PANI and PANI-Based Composite Adsorbents for the Removal of Organic Dyes and Other Organic Pollutants from Aqueous Environments

Polyaniline (PANI) and its derivatives possess significant detoxification characteristics and have been exclusively reported in the literature. The utilization of polyaniline nanoparticles as an adsorbent material for the removal of MB dye was reported by [45]. They reported that the synthesized material can be used as an efficient adsorbent for MB removal from water. The pseudo-second-order kinetic model was reported to fit well the experimental data. Moreover, they reported that using PANI nanoparticles and conventional PANI. The researchers concluded that PANI nanoparticles are more efficient adsorbents for $\mathrm{MB}$, compared with conventional PANI powdered adsorbents, and found that the pseudo-second-order kinetic model best described the experimental results.

In another research, the removal of reactive black 5 (RB-5) and reactive violet 4 (RV4) dyes was reported by [46], using PANI-starch nanocomposite. They reported high removal efficiencies of $99 \%$ and $98 \%$ for RB-5 and RV-4, respectively. Toth isotherm model was reported to best fit the equilibrium experimental data of both dyes. The main adsorption interactions between the adsorbent and the MB molecules reported are due to the availability of surplus hydrogen groups from the starch material. The ionic interactions were further confirmed by FTIR and desorption studies. Cationic dye, methylene blue (MB), and anionic dye, and Procion red (PR) removal from aqueous solutions using acid and base treated polyaniline were reported by [47]. Their experimental data were represented by the Langmuir isotherm equilibrium model. Furthermore, they stated that the cationic dye was mainly removed by the base-treated PANI, while the anionic dye was predominantly removed by the acid-treated PANI. The removal of an anionic dye, Rose Bengal (RB) aand a cationic dye, methylene blue (MB), from aqueous solutions using polyacid-doped polyaniline was reported by [48]. They reported maximum adsorption capacities of $440.00 \mathrm{mg} / \mathrm{g}$ for $\mathrm{RB}$ and $466.5 \mathrm{mg} / \mathrm{g}$ for MB. The adsorption mechanism reported involved $\pi-\pi$ interactions and electrostatic interactions. The pseudo-secondorder kinetic model and Langmuir isotherm equilibrium model followed the adsorption experimental data. In addition, the utilization of polyaniline in the form of nanoporous hyper-crosslinked polyaniline (HCPANI) for the removal of two types of dyes-cationic dye, crystal violet (CV) and anionic dye, methyl orange (MO) — was reported by [49]. The reported maximum adsorption capacities for the two dyes were $245 \mathrm{mg} / \mathrm{g}$ and $220 \mathrm{mg} / \mathrm{g}$ for $\mathrm{CV}$ and $\mathrm{MO}$, respectively. The main proposed interactions involved in the adsorption process of $\mathrm{CV}$ and $\mathrm{MO}$ dyes include $\pi-\pi$ interactions, hydrogen bonging, acid-Lewis-based interactions, as well as electrostatic interactions. 
Adsorption of various organic pollutants from aqueous and non-aqueous sources was reported by [50], using highly porous carbons obtained by the pyrolysis of polyaniline conductive polymer. High adsorption capacities were reported for various pollutants investigated. The reported mechanisms are mainly due to hydrogen bonding, in addition to $\pi-\pi$ interactions and/or hydrophobic interactions between the adsorbent (polyaniline-derived carbons, PDC-700, polyaniline-derived carbon activated at $700{ }^{\circ} \mathrm{C}$ ) and the adsorbates investigated. The adsorbent was tested for the successful removal of diethyl phthalate from an aqueous solution and for the removal of 4,6-dimethyldibenzothiophene from a model fuel. Various adsorption interactions between the adsorbent and adsorbate are reported including hydrophobic interactions, $\pi-\pi$ interactions, electrostatic interactions, hydrogen bonding, and acid-base interactions. Again, the very high adsorption capacity of the prepared adsorbent material for different organic pollutants is mostly due to the high porosity, high specific surface area, and presence of various functional groups.

Polyaniline-based nanocomposites are being increasingly used for the removal of organic pollutants and organic dyes. These include the work of [51] for the removal of MB dye from wastewater using polyaniline zirconium (VI) silicophosphate nanocomposites. The nature of the adsorption behavior of this composite was found to be spontaneous. The adsorption of $\mathrm{MB}$ on the reported adsorbent was reported to follow a second-order kinetic model, and the experimental data were best fitted by the Freundlich isotherm model. A maximum adsorption capacity of $12 \mathrm{mg} / \mathrm{g}$ was deduced from the Langmuir isotherm model fitting to the experimental data. Furthermore, methyl orange removal by polyaniline/MWCNTs $/ \mathrm{Fe}_{3} \mathrm{O}_{4}$ composites [52]. Another important paper concerned with the removaland decolorization, of Remazol effluent includes the work of [53], who reported the use of bacterial extracellular polysaccharides-polyaniline composites. Adsorption of brilliant green (BG) was reported by [54], using polyaniline/silver nanocomposites. In another paper, the removal of basic blue dye was reported [55], using polyaniline/magnetite $\left(\mathrm{Fe}_{3} \mathrm{O}_{4}\right)$ nanocomposites. Removal of another organic material such as tetracycline hydrochloride was reported by [56], using polypyrrole coated iron-doped titania-based hydrogel. Utilization of polyaniline-based adsorbents for the removal of dyes from water and wastewater was reported in detail in the review of [57]; some of the proposed mechanisms for MB removal by PANI are shown in Figure 3. Decolorization of Acid Blue 29 (an azo dye) was reported by [58] by utilizing PANI- $\mathrm{ZnO}-\mathrm{ZrO}_{2}$ composite as a photocatalyst in UV photocatalytic reactor. They reported that the composite showed better decolorization of the dye, compared with PANI alone.

In another research article, Rhodamine G6 (Rh-G6) was photocatalytically degraded by polyaniline-zinc sulfide (PANI-ZnS) nanocomposite with a removal efficiency of about $80 \%$, as reported by [59]. Photodegradation of MB and MG dyes by PANI-ZnO nanocomposite was reported by [60], in which the degradation was conducted under natural sunlight and under UV radiation. They reported high removal efficiencies for both dyes under natural sunlight exposure of $5 \mathrm{~h}$. In addition, the authors of [61] studied the removal of $\mathrm{MB}$ from an aqueous solution using PANI- $\mathrm{ZrO}_{2}$ nanocomposite. The effects of various process parameters on the adsorption characteristics were reported. The dye removal efficiency was found to increase with increasing contact time and operating temperature. The reported maximum adsorption capacity for the PANI-modified $\mathrm{ZrO}_{2}$ was found to be $77.55 \mathrm{mg} / \mathrm{g}$. Further, photodegradation of MB was reported by [62], using polyanilinezirconium silicophosphate (PANI-ZSP). The reported nanocomposite initially adsorbed the $\mathrm{MB}$ molecules on its surface active sites and then degraded the MB upon exposure to visible light. After two hours of exposure to visible light, a degradation efficiency of $82 \%$ was attained. 


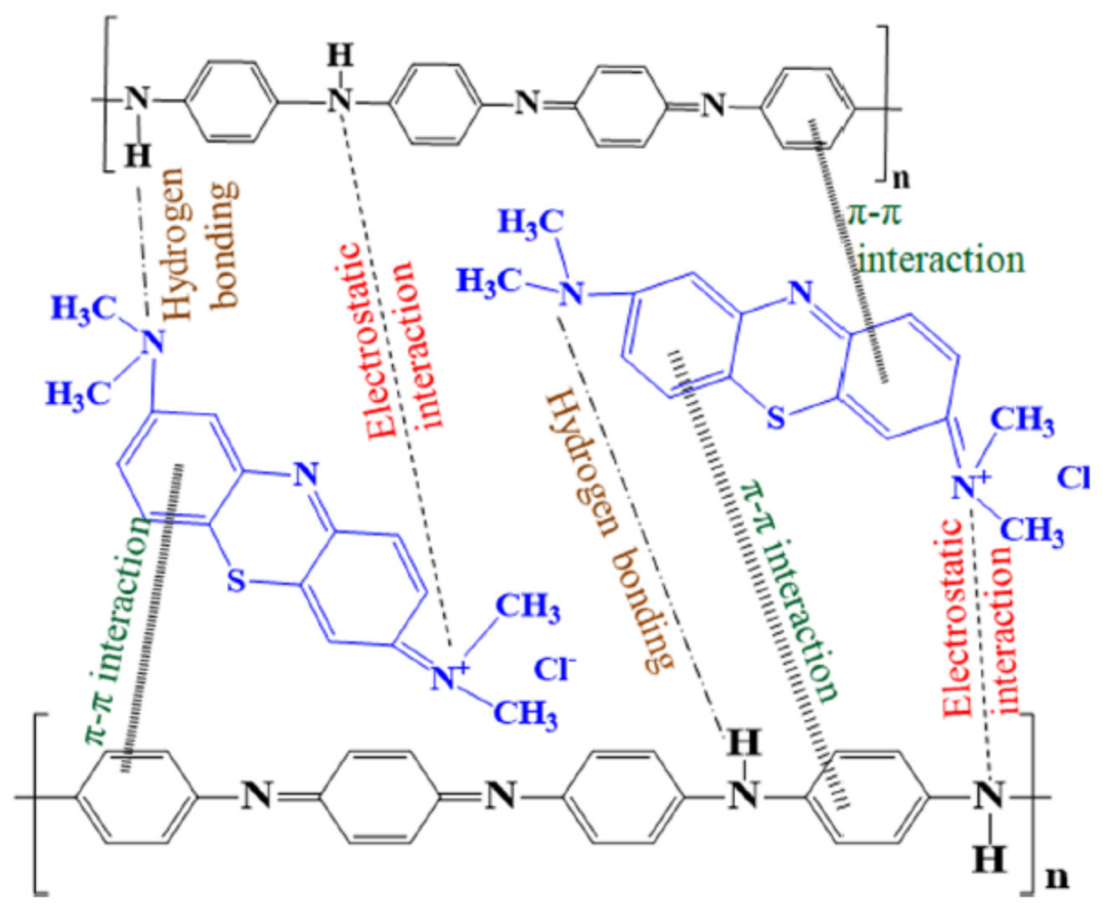

Figure 3. Different interactions proposed for the mechanism of methylene blue adsorption on polyaniline. Reprinted with permission from Ref. [57]. Copyright 2019 Springer Nature.

Organic pollutants other than organic dyes also require treatment before being discharged into the aquatic environment. The use of PANI and its derivatives have been extensively used as adsorbents for organic pollutants removal. For example, the removal of tannic acid from wastewater was reported by [63], using synthesized polyaniline. They reported that the Langmuir isotherm and pseudo-second-order kinetic models fitted well with the experimental data. A very high maximum adsorption capacity was observed at a high ionic strength of 2 moles per liter of $\mathrm{NaCl}$ solution. The nature of adsorption of tannic acid over the synthesized PANI was mainly suggested to be chemisorptions. The initial solution $\mathrm{pH}$ was reported to have a significant effect on the TA adsorption on PANI. The adsorbent-adsorbate interactions were mainly due to hydrogen bonding, electrostatic attraction, $\pi-\pi$ interactions, as well as a weak Van der Waals force. A more comprehensive list of various ODs and OPs removal by PANI and PANI-based adsorbents under various experimental conditions is provided in Table 3 below.

Table 3. PANI-based adsorbents for the removal of ODs and other organic pollutants.

\begin{tabular}{|c|c|c|c|c|c|}
\hline Adsorbent & Adsorbate & $\mathrm{pH}$ & $\begin{array}{c}\text { Temperature } \\
\left({ }^{\circ} \mathrm{C}\right)\end{array}$ & $\underset{(\mathrm{mg} / \mathrm{g})}{\mathrm{q}_{\max }}$ & Ref. \\
\hline PANI-SBA-15 & resorcinol & 3 & 25 & 128 & [33] \\
\hline HCPANI & $\begin{array}{l}\mathrm{MO} \\
\mathrm{CV}\end{array}$ & $\begin{array}{c}3, \\
11\end{array}$ & 27 & $\begin{array}{l}220 \\
245\end{array}$ & [49] \\
\hline PANI-ZSP & $\mathrm{MB}$ & 1 & 85 & 12 & [51] \\
\hline $\begin{array}{l}\text { PANI-MWCNTs- } \\
\mathrm{Fe}_{3} \mathrm{O}_{4} \text { magnetic } \\
\text { composite }\end{array}$ & $\begin{array}{c}\mathrm{MO} \\
\mathrm{CR}\end{array}$ & 4 & Room temp. & $\begin{array}{l}446.25 \\
417.38\end{array}$ & [52] \\
\hline $\begin{array}{c}\mathrm{Fe}_{3} \mathrm{O}_{4} \text { and } \\
\text { PANI- } \mathrm{Fe}_{3} \mathrm{O}_{4}\end{array}$ & BB-3 & $\begin{array}{l}8.5 \\
12 \\
10\end{array}$ & 30 & $\begin{array}{c}8.5 \\
6, \\
9\end{array}$ & [55] \\
\hline PANI-AC & $\mathrm{MO}$ & 6.5 & 25 & 285 & [64] \\
\hline PANI-AC & Direct Red 23 & 3.0 & 45 & 109.89 & [65] \\
\hline
\end{tabular}


Table 3. Cont.

\begin{tabular}{|c|c|c|c|c|c|}
\hline Adsorbent & Adsorbate & $\mathrm{pH}$ & $\begin{array}{c}\text { Temperature } \\
\left({ }^{\circ} \mathrm{C}\right)\end{array}$ & $\underset{(\mathrm{mg} / \mathrm{g})}{\mathrm{q}_{\max }}$ & Ref. \\
\hline PANI and PANI/AL & DG & 1 & 20 & $\begin{array}{c}0.911 \\
8.13\end{array}$ & {$[66]$} \\
\hline PANI-Chi & $\begin{array}{l}\text { CR, } \\
\text { CBB, } \\
\text { RBBR }\end{array}$ & 3 & 26 & $\begin{array}{l}322.58 \\
357.14 \\
303.03\end{array}$ & [67] \\
\hline PANI-MMT- $\mathrm{Fe}_{3} \mathrm{O}_{4}$ & $\mathrm{MB}$ & 6.3 & Room temp. & 184.48 & [68] \\
\hline PANI/CPL & $\mathrm{MO}$ & 4 & Room temp. & 333.33 & [69] \\
\hline $\begin{array}{l}\text { PANI, } \mathrm{Fe}_{3} \mathrm{O}_{4} \text {, and } \\
\text { PANI- } \mathrm{Fe}_{3} \mathrm{O}_{4}\end{array}$ & AB-40 & $3,6,6$ & 30 & $\begin{array}{l}130.5 \\
264.9 \\
216.9\end{array}$ & {$[70]$} \\
\hline PANI-Fe ${ }_{3} \mathrm{O}_{4}$ & MG & 7 & 25 & 4.82 & {$[71]$} \\
\hline PANI-HGL & $\mathrm{MB}$ & 6.5 & 45 & 71.2 & [72] \\
\hline PANI-LC & RB-5 & 2.0 & Room Temp. & 312 & [73] \\
\hline PANI-LC & CR & 4.29 & 45 & 1672.5 & [74] \\
\hline PANI-NFs/SD & $\mathrm{ARG}$ & 2.0 & 35 & 212.97 & [75] \\
\hline PANI-FeCl 3 & RB-5 & 6 & 45 & 434.7 & [76] \\
\hline PANI-NiFe ${ }_{2} \mathrm{O}_{4}$ & MG & 7 & $\mathrm{~N} / \mathrm{A}$ & 4.09 & [77] \\
\hline PANI-NiFe ${ }_{2} \mathrm{O}_{4}$ & ARS & 48.6 & 30 & 186 & [78] \\
\hline PANI-Ny-6 & $\mathrm{MO}$ & 1 & $\mathrm{~N} / \mathrm{A}$ & 370 & [79] \\
\hline PANI-ZnFe ${ }_{2} \mathrm{O}_{4}$ & RH-B & 2 & Room tem. & 229 & [80] \\
\hline
\end{tabular}

PANI and PANI-Based Composite Adsorbents for the Removal of Gaseous Pollutants

Utilization of PANI-derived porous and nitrogen-doped carbon materials with very high specific surface area for $\mathrm{CO}_{2}$ uptake was reported by [81]. This study focused on the adsorption of various gases such as $\mathrm{N}, \mathrm{CO}_{2}$, and $\mathrm{CH}_{4}$ over the prepared material and reported selective adsorption of $\mathrm{CO}_{2}$, compared with $\mathrm{N}$ and $\mathrm{CH}_{4}$, and relatively high capture capacity for the synthesized adsorbent for $\mathrm{CO}_{2}$ uptake. The nature of adsorption was reported to be physisorption or weak chemisorption. Removal of ammonia gas by PANI$\mathrm{TiO}_{2}$ as photocatalyst was reported by [82] under visible light and under UV radiation. They reported that the removal efficiency decreased as the reaction time increased.

Moreover, $\mathrm{CO}_{2}$ reduction to alcohol by polyaniline film was reported by [83]; their proposed reaction mechanisms are presented in Figure 4. Removal of various volatile organic compounds (VOCs) by various forms of polyaniline was reported by [84]. They reported that the main mechanisms which are at play in the removal of VOCs are the $\pi-\pi$ interactions between PANI backbone and the unsaturated hydrocarbons, which resulted in higher removal of unsaturated $(\mathrm{C}=\mathrm{C})$ bonds present in the target analytes. As for the saturated hydrocarbon-based VOCs, the main interactions are weak hydrogen bonding and weak Van der walls forces between PANI and the saturated molecules owing to the lack of available $\pi$ electrons. Overall, the type of PANI (EB or ES), surface area, morphology, and the type of doping agent (dopant) can significantly affect the VOC-PANI interactions and the removal performance. Adsorption of a flue gas $\mathrm{NO}_{2}$ by polyaniline-clay nanocomposite was reported by [85]. They reportedly prepared polyaniline composites with three different clays-namely, attapulgite (ATP), vermiculite (VEM), and diatomite (DIM), and concluded that the PANI-ATP composite revealed the high adsorption capacity for $\mathrm{NO}_{2}$ removal. Surface morphologies of some PANI-based adsorbents are presented in Figure 5. 


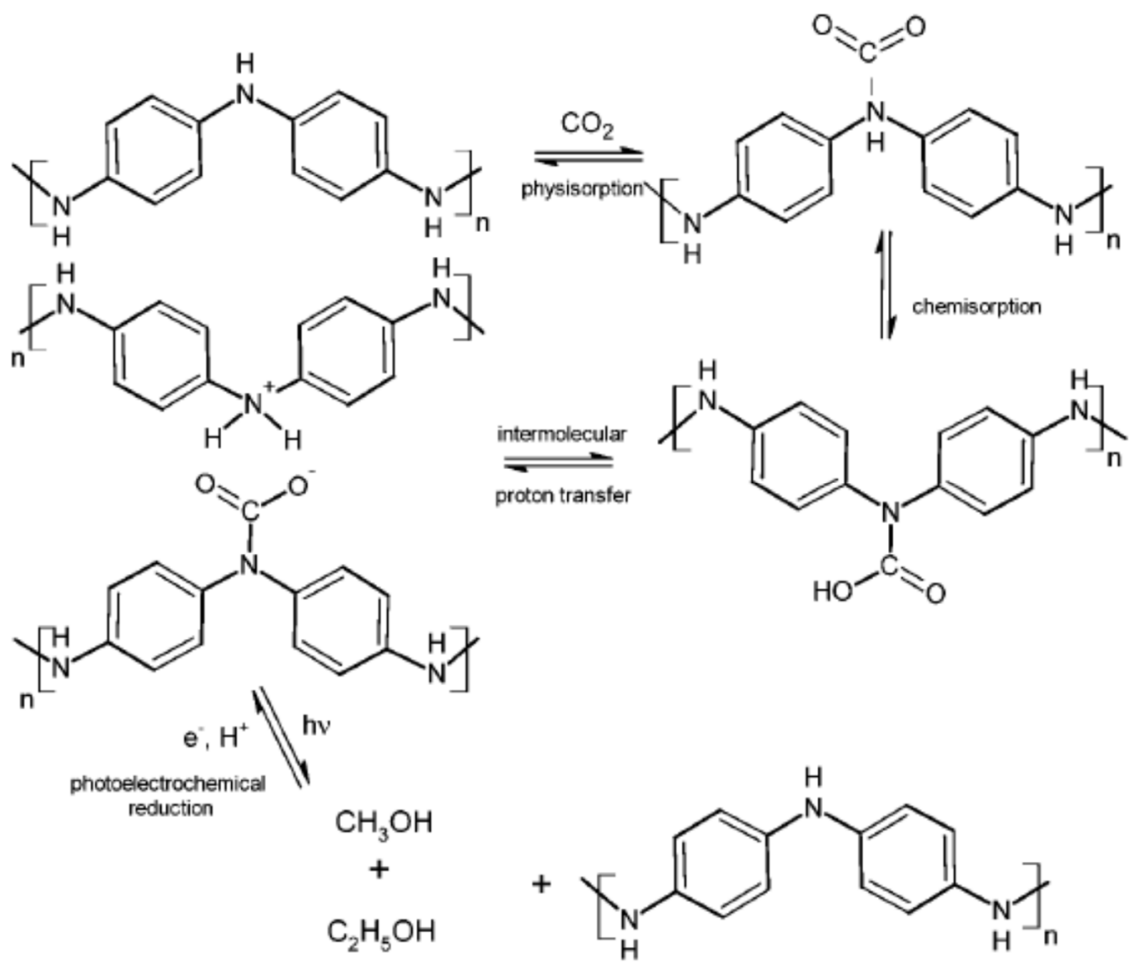

Figure 4. Possible reaction pathway for $\mathrm{CO}_{2}$ adsorption and photoelectroreduction on PANI. Reproduced from Ref. [83]. Copyright 2016 Royal Society of Chemistry.

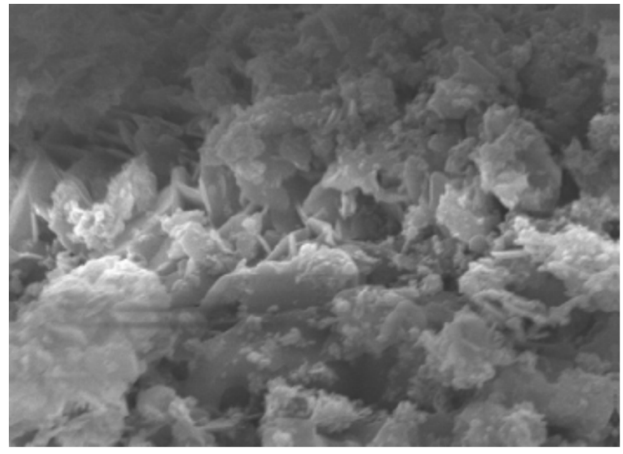

(a)

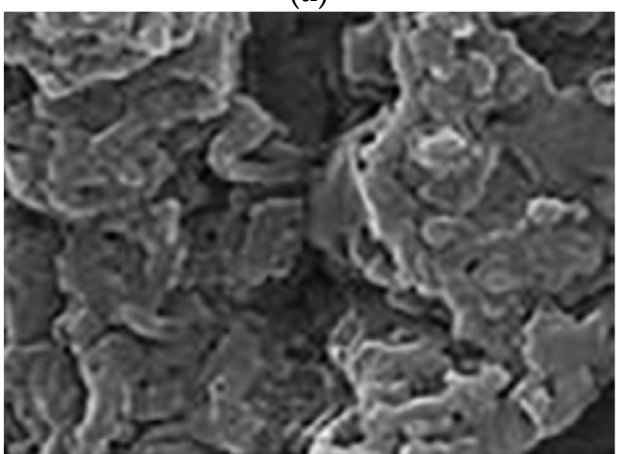

(c)

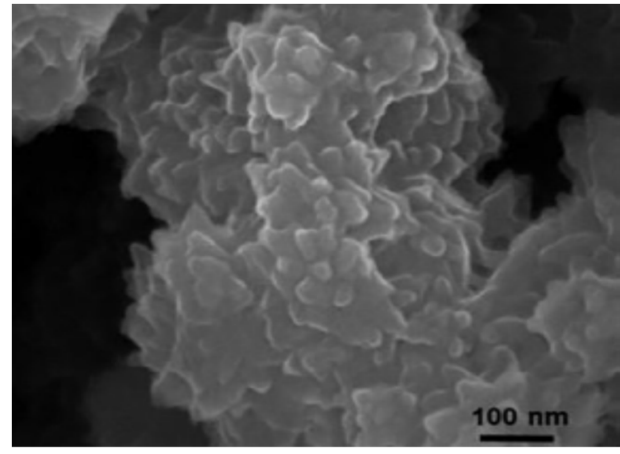

(b)

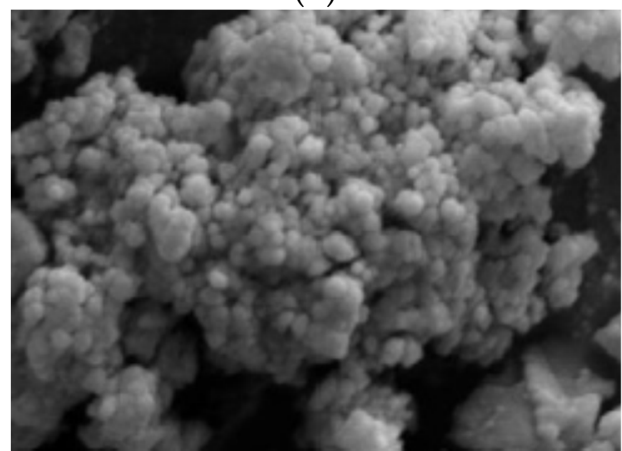

(d)

Figure 5. Cont. 


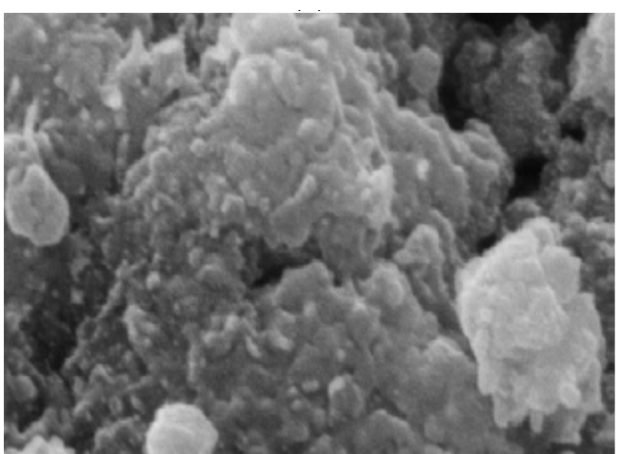

(e)

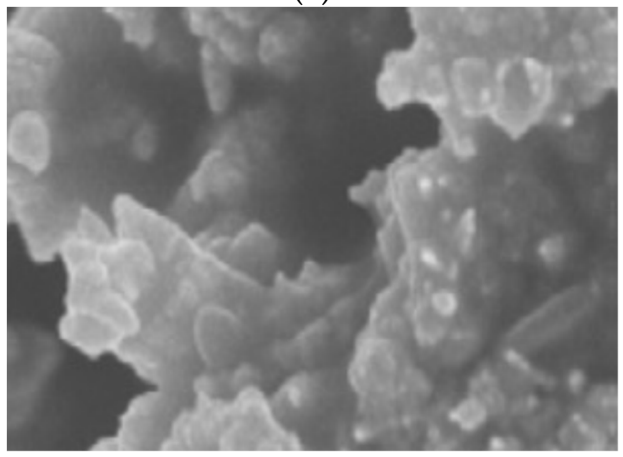

(g)

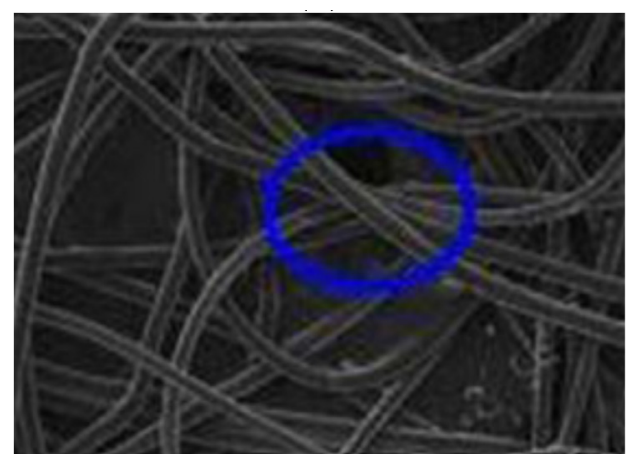

(f)

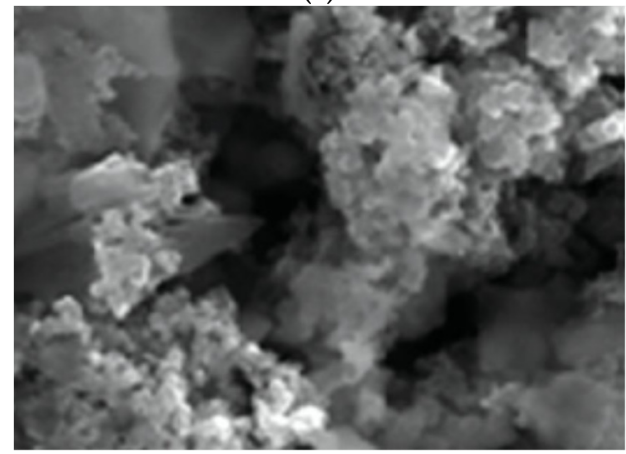

(h)

Figure 5. SEM images of some representative PANI and PANI-based polymer composites. (a) Reprinted with permission from Ref. [86]. Copyright 2017 Elsevier. (b) Reprinted with permission from Ref. [87]. Copyright 2019 Elsevier. (c) Reprinted with permission from Ref. [88]. Copyright 2018 Elsevier. (d) Reprinted with permission from Ref. [89]. Copyright 2018 Elsevier. (e) Reprinted with permission from Ref. [90]. Copyright 2010 Elsevier. (f) Reprinted with permission from Ref. [91]. Copyright 2013 Elsevier. (g) Reprinted with permission from Ref. [92]. Copyright 2014 Elsevier. (h) Reprinted with permission from Ref. [93]. Copyright 2013 Wiley Periodicals, Inc.

\subsection{Polypyrrole-Based Nanocomposites as Adsorbents}

\subsubsection{HMIs Removal by Ppy and Ppy-Based Composite Adsorbents}

Hexavalent chromium removal by exfoliated polypyrrole-organically modified MMT clay nanocomposites was reported by [94]. The researcher reported that the kinetic data fitted well the PSO kinetic model, while the equilibrium data were best fitted by the Langmuir model. Additionally, they concluded that an increase in maximum adsorption capacity from 112 to $209 \mathrm{mg} / \mathrm{g}$ at temperatures 19 to $45^{\circ} \mathrm{C}$. Polypyrrole-functionalized chitin was used for $\mathrm{Cr}$ (VI) removal by [95], who reported that the Freundlich isotherm model fitted well the experimental data. The reported maximum adsorption capacities ranged from approximately 29 to 35 at $30-50{ }^{\circ} \mathrm{C}$ temperature. The adsorption process was reported to be spontaneous and endothermic. $\mathrm{Cr}$ (VI) by polypyrrole-wrapped MWCNTs nanocomposites was reported by [96], who found a maximum adsorption capacity of $294 \mathrm{mg} / \mathrm{g}$. They also reported good fitting of the experimental data by the Langmuir model and the spontaneous and endothermic nature of adsorption for $\mathrm{Cr}$ (VI) removal. Threoninedoped polypyrrole nanocomposites for $\mathrm{Cr}(\mathrm{VI})$ removal were reported by [97]. Additionally, the removal of $\mathrm{Cr}$ (VI) from wastewater was reported by [98], using polypyrrole/2,5diaminobenzene sulfonic acid composite and by glycine doped polypyrrole composite [99].

Uranium (VI) ions removal by polypyrrole was investigated by [100] in a batch system and reported that the Freundlich isotherm model was in good agreement with their experimental data. A maximum adsorption capacity of $87.72 \mathrm{mg} / \mathrm{g}$ was deduced from the Langmuir isotherm model and the pseudo-second-order kinetic model showed a better correlation. They also reported the endothermic and spontaneous nature of the adsorption process for uranium (VI) ions by exploring the thermodynamic data of their work. The 
use of polypyrrole for the removal of copper ions from aqueous solutions was reported by [101], who stated that the Langmuir isotherm model fitted well the experimental data. They also concluded that the available amine functional groups for ion exchange in polypyrrole made it a good adsorbent. The removal of $\mathrm{Cr}$ (VI) from aqueous solutions using bamboo-like polypyrrole nanotubes was reported by [102], who observed higher adsorption performance for their synthesized nanotubes, compared with conventional polypyrrole adsorbents for $\mathrm{Cr}(\mathrm{VI})$ removal.

In another paper, removal of $\mathrm{Cr}$ (VI) from aqueous solution was reported [103], using polypyrrole/monodisperse latex spheres and also by using polypyrrole/calcium rectorite composite [104]. Further, the removal of $\mathrm{Cr}$ (VI) and $\mathrm{Cu}$ (II) metal ions from aqueous media was reported by [105], using polypyrrole-maghemite magnetic nanocomposites. The removal of another heavy metal $\mathrm{Hg}$ (II) ions by polypyrrole-functionalized $\mathrm{CoFe}_{2} \mathrm{O}_{4} @ \mathrm{SiO}_{2}$ was reported by [106]. Adsorption of heavy metal $\mathrm{Pb}$ (II) ions in polypyrrole-bentonite nanocomposites [107] and in polypyrrole- $\mathrm{Fe}_{3} \mathrm{O}_{4}$ nanosized magnetic adsorbents were also reported [108]. The removal of cadmium Cd (II) ions from wastewater was reported by [109], using polypyrrole- $\mathrm{TiO}_{2}$ nanocomposites. A detailed review on the utilization bio-composites coated by polypyrrole was reported by [110], while another study pointed to microbial fuel cells, coupled with Fenton oxidation [111], for the removal of heavy metal ions from wastewater. Polypyrrole-coated sawdust of dryobalanops aromatic for the adsorption of cadmium-109 isotopes was reported by [112]. The removal of arsenic from wastewater was reported by [113], using polypyrrole composites with bentonite and activated carbon. Some of the proposed adsorption mechanisms for $\mathrm{Cr}$ (VI) removal by polypyrrole-modified magnetic nanocomposites are demonstrated in Figure 6. In addition, some HMIs removal by polypyrrole-modified adsorbents are listed in Table 4 .

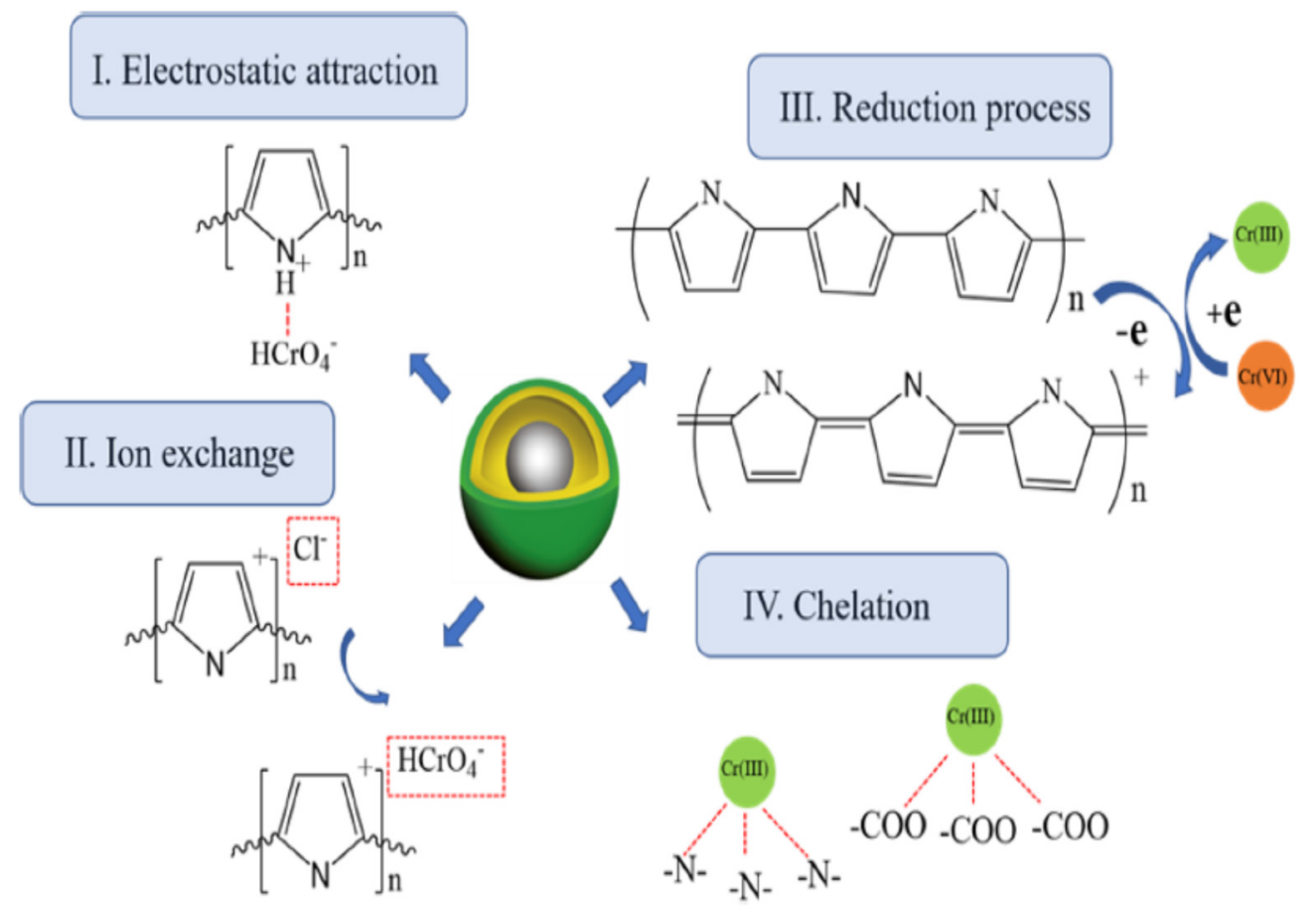

Figure 6. Possible adsorption mechanism of Cr (VI) removal by magnetic-UiO66-Ppy. Reprinted with permission from Ref. [114]. Copyright 2021 Springer Nature. 
Table 4. Ppy-based adsorbents for the removal of HMIs.

\begin{tabular}{cccccc}
\hline Adsorbent & Adsorbate & $\mathbf{p H}$ & $\begin{array}{c}\text { Temperature } \\
\left({ }^{\circ} \mathbf{C}\right)\end{array}$ & $\begin{array}{c}\text { qmax } \\
(\mathbf{m g} / \mathbf{g})\end{array}$ & Ref. \\
\hline Ppy-PANI & $\mathrm{Cr}(\mathrm{VI})$ & 2 & 25 & 227 & {$[115]$} \\
Ppy-oMMT NC & $\mathrm{Cr}(\mathrm{VI})$ & 2 & 25 & 209.6 & {$[94]$} \\
Ppy-Chitin & $\mathrm{Cr}(\mathrm{VI})$ & 2 & 50 & 35.22 & {$[95]$} \\
Ppy/Fe $\mathrm{O}_{4}$ and & & & 45 & 243.9, & {$[96]$} \\
Ppy/oMWCNTs & $\mathrm{Cr}(\mathrm{VI})$ & 2 & 25 & 294 & \\
NC & & & 25 & 303 & {$[98]$} \\
Ppy/DABSA & $\mathrm{Cr}(\mathrm{VI})$ & 2 & 45 & 232.55 & {$[99]$} \\
Ppy-gly & $\mathrm{Cr}(\mathrm{VI})$ & 2 & 25 & 343.64 & {$[103]$} \\
Ppy/MLS & $\mathrm{Cr}(\mathrm{VI})$ & 2 & 45 & 833.33 & {$[104]$} \\
Ppy/Ca-REC & $\mathrm{Cr}(\mathrm{VI})$ & 1.5 & 55 & 173.16 & {$[108]$} \\
Ppy-Fe 3 O & $\mathrm{H}$ & 2.5 & 45 & 9.13 & {$[116]$} \\
Ppy-BOFS NC & $\mathrm{Hg}{ }_{2+}$ & 2 & 25 & 429.2 & {$[117]$} \\
Ppy-GSi NC & $\mathrm{Cr}(\mathrm{VI})$ & 2 & &
\end{tabular}

2.3.2. Removal of Organic Pollutants and Organic Dyes by Ppy and Ppy-Based Composite Adsorbents

Different organic pollutants including organic dyes may present significant threats to the environment and to human health. However, their removal and remediation from wastewater were reported by numerous researchers. These include, for example, the removal of MB from aqueous solution using polypyrrole-coated cotton fabrics [118] and polypyrrole- $\mathrm{TiO}_{2}$ composites [119], as well as the removal of Congo red by molecularly imprinted polypyrrole-coated magnetic $\mathrm{TiO}_{2}$ nanoparticles. Removal of naphthol green $\mathrm{B}$ from aqueous solution was reported by [120] using polypyrrole/Attapulgite composites. The removal of acidic dye namely Congo red by various polypyrrole-based composite adsorbents was reported by [121]. The adsorption behavior of various anionic and cationic organic dyes was reported by [122] by using polypyrrole-SBA-15 nanocomposites. The removal of another dye, atrazine, by nylon-polypyrrole core shells nanofibers mat was reported by [123]. A well-detailed review for the utilization of polypyrrole-based composite was reported by [124] for the removal of acid dyes. Polypyrrole nanofibers with hierarchical structure for the removal of acid red G (azo dye) were reported by [125]. They reported a maximum adsorption capacity of $121.95 \mathrm{mg} / \mathrm{g}$ for their investigated dye. Further, Ppy-MWCNT nanocomposite was used as an adsorbent for the removal of a non-steroid anti-inflammatory drug (potassium diclofenac) from an aqueous solution [126]. They reported that the modification of MWCNT by Ppy has significantly improved the maximum adsorption capacity and that the thermodynamic parameters suggested endothermic and favorable adsorption. Further, polypyrrole-based adsorbent-namely, polypyrrolefunctionalized Calotropis gigantea fibers are being successfully used for the removal of three fluoroquinolone antibiotics from wastewater, as reported by [127]. The prepared adsorbent exhibited superior adsorption capacities for the investigated antibiotics. Further, they reported that the main adsorption mechanism may be hydrophobic interactions, electrostatic interactions, ion exchange, $\pi-\pi$ interactions, and hydrogen bonding. Figure 7 shows some of the proposed adsorption mechanisms for organic dye removal by polypyrrole. Adsorption of another organic compound, 4-nitrophenol, by polypyrrole-bentonite clay nanocomposite was reported by [128]. A maximum adsorption capacity of $96 \mathrm{mg} / \mathrm{g}$ of adsorbent was reportedly deduced from the Langmuir isotherm model. The thermodynamic parameters suggested an exothermic adsorption process. In another important work, the simultaneous removal of various polycarboxy-benzoic acids by polypyrrole-nut shells of argan (Ppy-NA) was reported by [129]. They reported relatively high adsorption capacity of the prepared adsorbent material for all acids. They reported that the adsorption process is spontaneous and endothermic in nature. Furthermore, the removal of some organic dyes by conductive polymers is listed in Table 5 . 


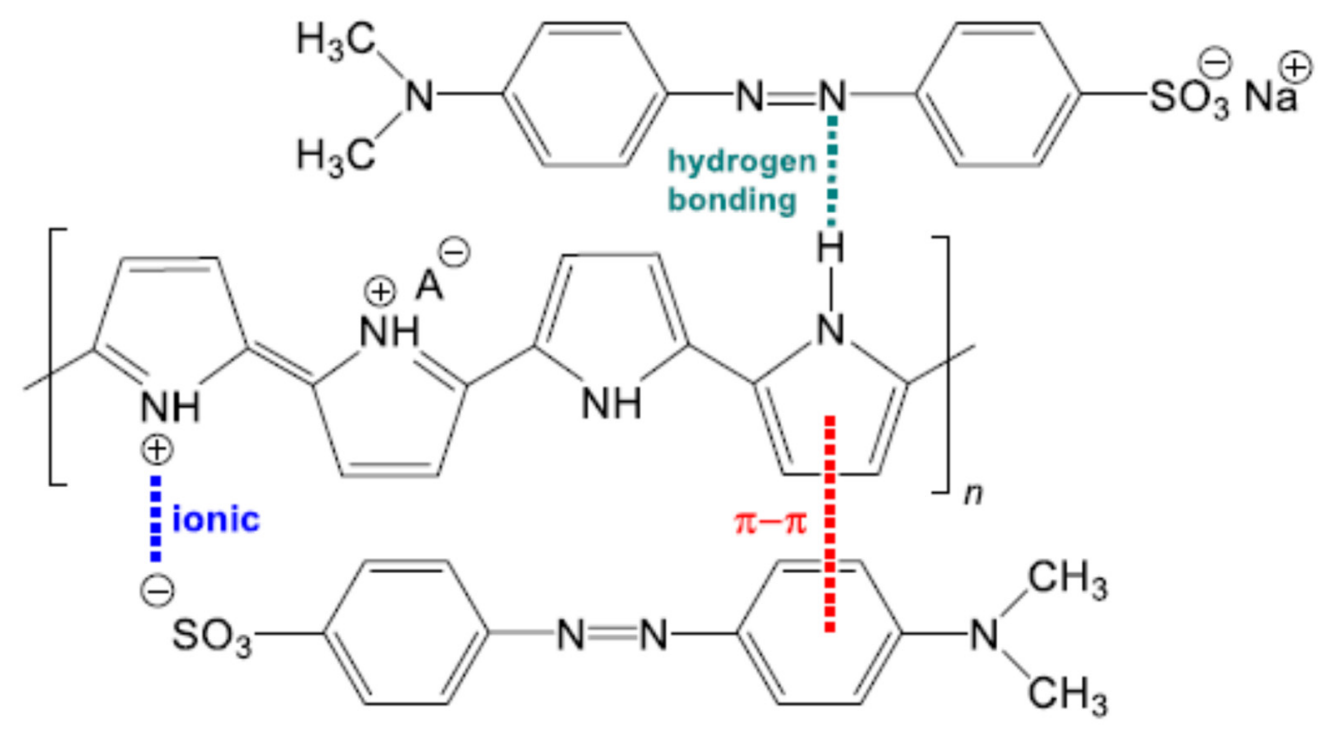

Figure 7. $\pi-\pi$ interactions and hydrogen bonding between organic dye methyl orange and Ppy. Reprinted with permission from Ref. [130]. Copyright 2019 Springer Nature.

Table 5. Ppy-based adsorbents for the removal of ODs.

\begin{tabular}{|c|c|c|c|c|c|}
\hline Adsorbent & Adsorbate & $\mathrm{pH}$ & $\begin{array}{c}\text { Temperature } \\
\left({ }^{\circ} \mathrm{C}\right)\end{array}$ & $\underset{(\mathrm{mg} / \mathrm{g})}{\mathrm{q}_{\max }}$ & Ref. \\
\hline Ppy-PANI NF & $\mathrm{CR}$ & 4 & 35 & 270.27 & {$[131]$} \\
\hline Ppy NF & ARG & 2 & 25 & 121.95 & {$[125]$} \\
\hline Ppy-CF & $\mathrm{MB}$ & 12 & Room Temp. & 6.0 & {$[118]$} \\
\hline $\mathrm{Ppy} / \mathrm{TiO}_{2}$ & MB & 13 & $35^{1}$ & 298.50 & [119] \\
\hline $\begin{array}{c}\text { Ppy-Attapulgite- } \\
\text { ZVI }\end{array}$ & NG-B & 2 & 45 & 253.9 & {$[120]$} \\
\hline Ppy-Chi-LS & CR & 2 & 50 & 30.12 & {$[121]$} \\
\hline Ppy-SBA-15 NC & $\begin{array}{l}\mathrm{MB} \\
\mathrm{MO}\end{array}$ & $\begin{array}{l}4.5 \\
6.5\end{array}$ & 20 & $\begin{array}{l}58.82 \\
41.66\end{array}$ & {$[122]$} \\
\hline Ppy-PA6 NFM & atrazine & 7 & 70 & 14.8 & {$[123]$} \\
\hline Ppy-SD & $\mathrm{AO}-10$ & 3 & 45 & 256.41 & {$[124]$} \\
\hline Ppy-BNT NC & $\begin{array}{c}4- \\
\text { nitrophenol }\end{array}$ & $\mathrm{N} / \mathrm{A}$ & 25 & 96.15 & {$[128]$} \\
\hline Ppy- $\alpha$ Cellulose & RR-120 & 2 & 25 & 96.1 & {$[132]$} \\
\hline $\mathrm{Ppy}-\mathrm{Chi}-\mathrm{Fe}_{3} \mathrm{O}_{4}$ & AG-25 & $\mathrm{N} / \mathrm{A}$ & Room temp. & 32.754 & [133] \\
\hline Ppy-CF & $\mathrm{MB}$ & 10 & 25 & 3.30 & {$[134]$} \\
\hline Ppy/SD & MB & 2 & Room temp. & 34.36 & {$[135]$} \\
\hline
\end{tabular}

\subsubsection{Gaseous Pollutants Removal by Ppy and Ppy-Based Composite Adsorbents}

Removal of gaseous pollutants by Ppy and Ppy-based composite adsorbents is relatively scarce in the literature. However, adsorption of $\mathrm{CO}_{2}$ on porous rodlike polypyrrole structure was reported by [136], who concluded that the maximum $\mathrm{CO}_{2}$ uptake was $173.885 \mathrm{~mL} / \mathrm{g}$ at 195K for Ppy synthesized without any surfactant.

\subsection{Polythiophene and Other Conductive Polymer Nanocomposites as Adsorbents}

Polythiophenes and their derivatives are rarely used as adsorbents for the removal of potentially hazardous pollutants. However, the environmental remediation of $\mathrm{Cr}$ (III) using polythiophenes-based adsorbent with a maximum adsorption capacity of $85.79 \mathrm{mg} / \mathrm{g}$ was reported by [137]. The removal of organic dye methylene blue using polythiophenemodified adsorbents was reported by [138], with relatively high adsorption capacities. The experimental data were reported to be best described by the pseudo-second-order kinetic model, while the thermodynamic parameters reportedly suggested a spontaneous and endothermic nature of the adsorption process. As a photocatalyst, polythiophene-based 
nanocomposites were reported for the removal of MB and MO by [139], under visible LED and natural sunlight. The prepared nanocomposite was reported to have excellent photocatalytic and adsorption activity, while the prepared material can be easily separated from the solution after equilibrium by the use of an external magnet. Photodegradation of $\mathrm{MB}$ was also reported by [140], using polythiophene-doped $\mathrm{SrTiO}_{3}$ nanocomposite, and reported better catalytic activity for the prepared nanocomposite, compared with the starting materials, i.e., polythiophene and $\mathrm{SrTiO}_{3}$. In another study, removal of arsenic ions by sawdust, modified by the three well-known CPs-namely, PANI-SD, Ppy-SD, and PTh-SD, was reported by [141]. The study concluded that PTh-SD adsorbent showed the highest adsorption capacity, compared with unmodified SD, PANI-SD, and PpySD samples. The exact adsorption mechanism was clearly stated, but three possible reactions were proposed that include chemical oxidation, anion exchange, and chelation processes. Furthermore, it was reported by [142] that Cd (II) can be efficiently removed by polythiophene nanocomposites. Likewise, the use of polythiophene as an adsorbent material was reported by [143] for the removal of toxic As (III). In the reported adsorption process, the As ions become attached to $\pi$ electrons at the backbone of the polymer, leading to much stronger interactions between $S$ and As atoms.

\section{Pollutants Removal by Combined Conductive Polymers}

The use of combined conductive polymers for pollutants removal has been reported by various researchers. For example, PANI-Ppy nanofibers for the removal of $\mathrm{Cr}(\mathrm{VI})$ were reported by [115]. Similarly, the use of PANI-Ppy copolymer nanofibers for the removal of cobalt ions Co (II) from aqueous solutions was reported by [144]. They emphasized the positive role of temperature on the adsorption process and reported $99.68 \%$ removal efficiency for a $100 \mathrm{mg} / \mathrm{L}$ Co (II) concentration at the optimum operating conditions. Similarly, the removal of Congo red (CR) from aqueous solutions using PANI-Ppy nanofibers was reported by [131] in a batch adsorption model, indicating higher removal efficiencies for $\mathrm{CR}$ at low solution $\mathrm{pH}$. They also reported good fitting of the Langmuir isotherm equilibrium model and pseudo-second-order kinetic model to their experimental data. A higher adsorption capacity was observed for PANI nanofibers (270.27 mg/g), compared with Ppy nanofibers (222.22 mg/g). Further utilization of conductive polymers as adsorbents for nitrates from wastewater was reported by [145], using polyaniline and polypyrrole as adsorbents. They reported that the Langmuir isotherm model fitted well the experimental data and that the adsorption process followed the pseudo-second-order kinetic model. The nature of the adsorption of nitrates on PANI and Ppy was spontaneous. However, higher adsorption capacities for nitrates were observed by PANI, compared with Ppy. The removal of Congo red was reported for PANI and Ppy adsorbents in another paper by [146], who observed that removal efficiencies increased with increasing contact time and adsorbent dosage. They reported good fitting of the Langmuir equilibrium isotherm and pseudosecond-order kinetic models with their experimental data. In another research article, methylene blue (MB) removal using polyaniline and polypyrrole macro-nanoparticles was reported [147]. The reported maximum adsorption capacity for the synthesized nanoparticles was $19.2 \mathrm{mg} / \mathrm{g}$ of MB/g of polymer. Additionally, a detailed review on the utilization of conducting polymers as adsorbents for the removal of textile dyes was reported by [57]. Various surface morphologies possessed by polypyrrole-modified adsorbents are presented in Figure 8 below. 


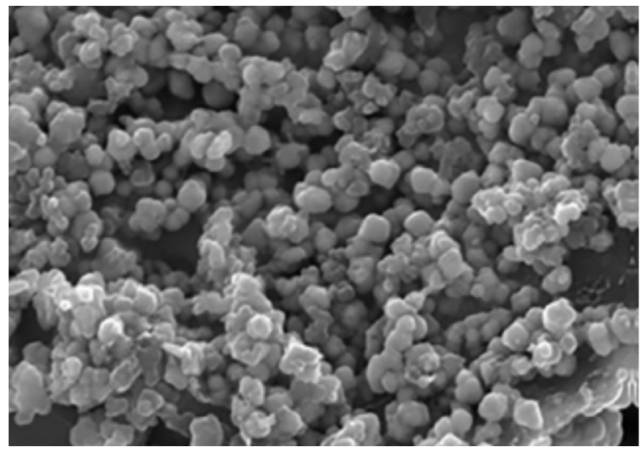

(a)

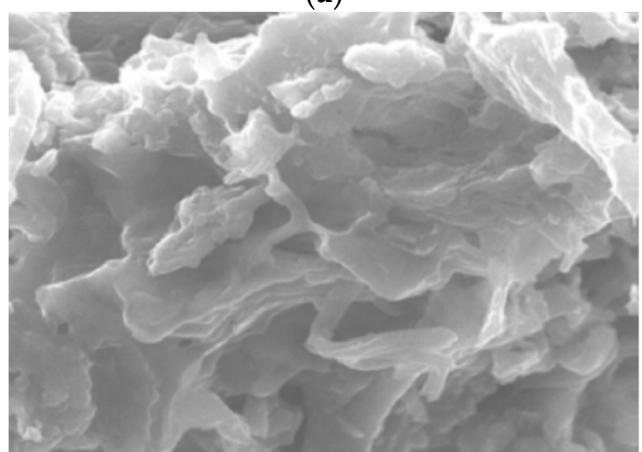

(c)

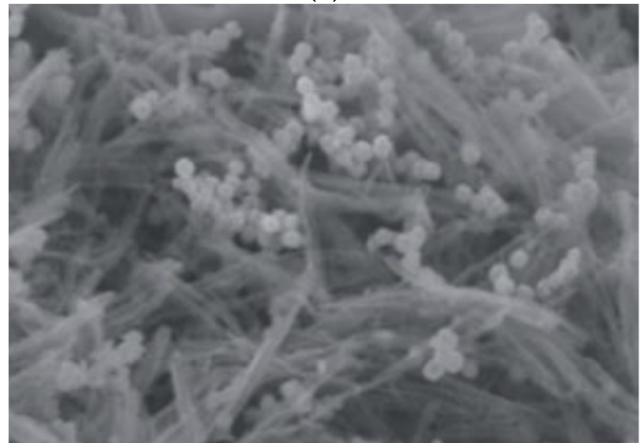

(e)

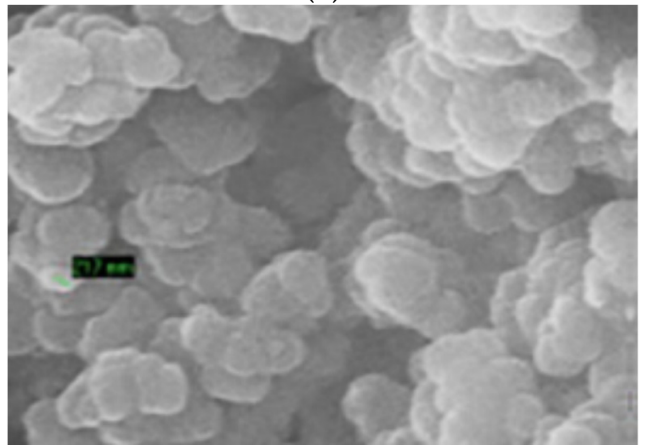

(g)

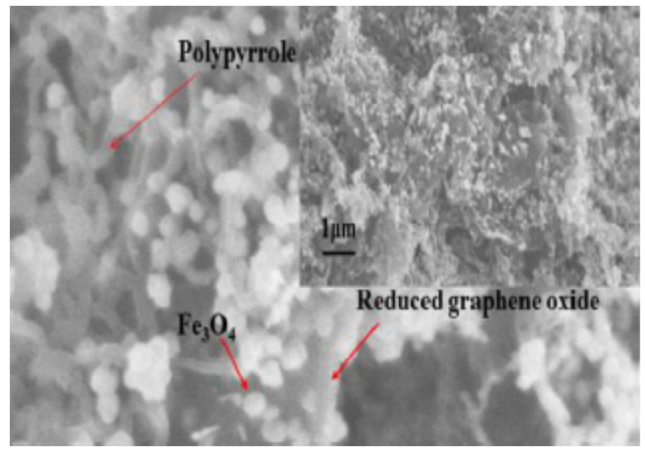

(b)

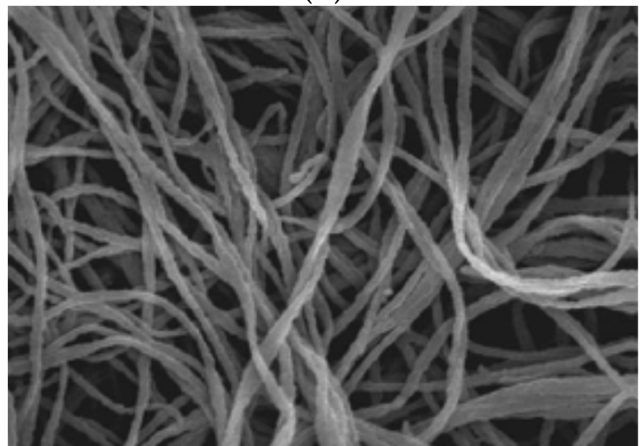

(d)

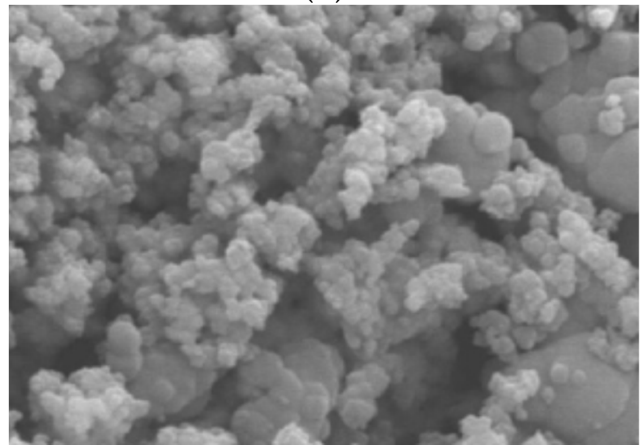

(f)

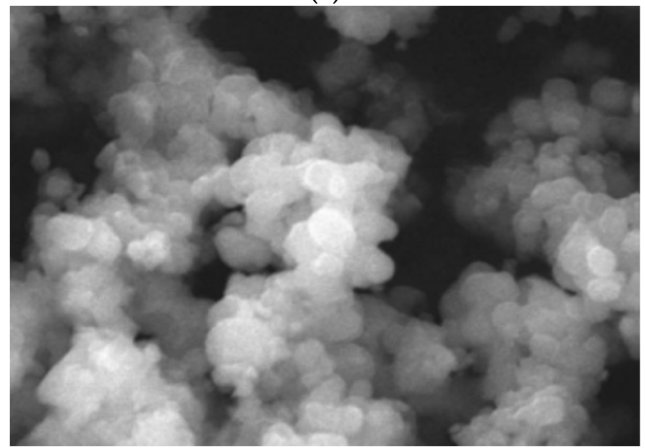

(h)

Figure 8. Some representative SEM images of Ppy and Ppy-based composite materials. (a) Magnetic $\mathrm{Fe}_{3} \mathrm{O}_{4} @$ Arg-Ppy nanocomposite. Reprinted with permission from Ref. [148]. Copyright 2018 Elsevier. (b) $\mathrm{Ppy}-\mathrm{Fe}_{3} \mathrm{O}_{4} / \mathrm{rGO}$ composite. Reprinted with permission from Ref. [149]. Copyright 2014 Elsevier. (c) Ppy-Nutshell of Argan composite. Reprinted with permission from Ref. [129]. Copyright 2016 Elsevier. (d) Ppy-Bacterial Cellulose Fiber composite. Reprinted with permission from Ref. [150]. Copyright 2021 
Springer Nature. (e) Ppy-mixed oxide nanocomposite. Reproduced from Ref. [151]. Copyright 2018 Royal Society of Chemistry. (f) $\mathrm{Ppy}_{-} \mathrm{TiO}_{2}$ nanocomposite. Reprinted with permission from Ref. [152]. Copyright 2012 Elsevier. (g) Ppy-Magnetic Corncomb Biochar composite. Reprinted with permission from Ref. [153]. Copyright 2018 Elsevier. (h) $\mathrm{Fe}_{3} \mathrm{O}_{4}-\mathrm{TiO}_{2}-\mathrm{Ppy}$ nanocomposite. Reprinted with permission from Ref. [154]. Copyright 2016 Springer Nature.

\section{Conclusions}

Conductive polymers and their composites are known to be efficient adsorbents for various types of pollutants and contaminants. This is mostly due to their interesting redox characteristics and the presence of $\mathrm{N}, \mathrm{S}, \mathrm{P}$, and $\mathrm{O}$ elements in their chemical structure. The most predominant reported mechanisms for organic dyes removal are $\pi-\pi$ interactions, hydrogen bonding, hydrophobic interactions, acid-base interactions, and electrostatic interactions. As for the heavy metal ions removal, the most common mechanisms are electrostatic attraction, ion exchange, chelation, and reduction. Among the heavy metals, removal of $\mathrm{Cr}$ (VI) is the most widely studied contaminant, while among the organic dyes, methylene blue is reportedly the most widely studied pollutant. Overall, it may be concluded that modification by conductive polymers of various types of potential adsorbent materials leads to significant improvements in the adsorption rates and maximum adsorption capacities of the unmodified adsorbents. Among the conductive polymers, polyaniline and polypyrrole have been extensively studied as potential adsorption enhancers (leading to significantly high maximum adsorption capacities), compared with polythiophenes. Hence, polythiophenes and their derivates may present opportunities for further exploration and research.

Funding: This research was funded by the Deanship of Scientific Research at King Khalid University, Saudi Arabia, through research groups program under grant number R.G.P 1/196/41.

Institutional Review Board Statement: Not applicable.

Informed Consent Statement: Not applicable.

Conflicts of Interest: The Authors declare no conflict of interest.

\section{References}

1. Derdour, K.; Bouchelta, C.; Naser-Eddine, A.K.; Medjram, M.S.; Magri, P. Removal of Cr (VI) from aqueous solutions by using activated carbon supported iron catalysts as efficient adsorbents. World J. Eng. 2018, 15, 3-13. [CrossRef]

2. Briggs, D. Environmental pollution and the global burden of disease. Br. Med. Bull. 2003, 68, 1-24. [CrossRef]

3. Aigbe, U.O.; Osibote, O.A. A review of hexavalent chromium removal from aqueous solutions by sorption technique using nanomaterials. J. Environ. Chem. Eng. 2020, 8, 104503. [CrossRef]

4. Nasseh, N.; Taghavi, L.; Barikbin, B.; Harifi-Mood, A.R. The removal of Cr (VI) from aqueous solution by almond green hull waste material: Kinetic and equilibrium studies. J. Water Reuse Desalination 2016, 7, 449-460. [CrossRef]

5. Ali, I.H.; Al Mesfer, M.K.; Khan, M.I.; Danish, M.; Alghamdi, M.M. Exploring Adsorption Process of Lead (II) and Chromium (VI) Ions from Aqueous Solutions on Acid Activated Carbon Prepared from Juniperus procera Leaves. Processes 2019, 7, 217. [CrossRef]

6. Sorme, L.; Lagerkvist, R. Sources of heavy metals in urban wastewater in Stockholm. Sci. Total Environ. 2002, 298, 131-145. [CrossRef]

7. Chaari, I.; Medhioub, M.; Jamoussi, F.; Hamzaoui, A.H. Acid-treated clay materials (Southwestern Tunisia) for removing sodium leuco-vat dye: Characterization, adsorption study and activation mechanism. J. Mol. Struct. 2021, 1223, 128944. [CrossRef]

8. Ameen, S.; Seo, H.-K.; Akhtar, M.S.; Shin, H.S. Novel graphene/polyaniline nanocomposites and its photocatalytic activity toward the degradation of rose Bengal dye. Chem. Eng. J. 2012, 210, 220-228. [CrossRef]

9. Sani, F.M.; Oyelaran, O.A. Exhaust Gas Treatment in Thermal Power Plants: A Review. Int. J. Adv. Sci. Res. Eng. 2019, 5, 227-233. [CrossRef]

10. Demirci, S.; Sahiner, N. The Use of Conductive Polymers Embedded Macro Porous Pei and Ionic Liquid Form of Pei Cryogels for Potential Conductometric Sensor Application to $\mathrm{CO}_{2}$. J. Compos. Sci. 2020, 4, 27. [CrossRef]

11. Kausar, A.; Siddiq, M. Conducting Polymer/Graphene Filler-based Hybrids: Energy and Electronic Applications. In Polymer Science: Research Advances, Practical Applications and Educational Aspects; Méndez-Vilas, A., Solano-Martín, A., Eds.; Formatex Research Center: Badajoz, Spain, 2016; pp. 177-187. Available online: https://pdfs.semanticscholar.org/4376/5a93a70d59fa5d4 aa8f9c667422c66c6f18a.pdf (accessed on 3 April 2021). 
12. Kumar, H.; Kumari, N.; Sharma, R. Nanocomposites (conducting polymer and nanoparticles) based electrochemical biosensor for the detection of environment pollutant: Its issues and challenges. Environ. Impact Assess. Rev. 2020, 85, 106438. [CrossRef]

13. Geetha, S.; Rao, C.R.; Vijayan, M.; Trivedi, D. Biosensing and drug delivery by polypyrrole. Anal. Chim. Acta 2006, 568, 119-125. [CrossRef]

14. Nicolas-Debarnot, D.; Poncin-Epaillard, F. Polyaniline as a new sensitive layer for gas sensors. Anal. Chim. Acta 2003, 475, 1-15. [CrossRef]

15. Khan, M.I.; Chaudhry, A.U.; Hashim, S.; Zahoor, M.K.; Iqbal, M.Z. Recent developments in intrinsically conductive polymer coatings for corrosion protection. Chem. Eng. Res. Bull. 2010, 14, 73-86. [CrossRef]

16. Zarras, P.; Anderson, N.; Webber, C.; Irvin, D.; Irvin, J.; Guenthner, A.; Stenger-Smith, J. Progress in using conductive polymers as corrosion-inhibiting coatings. Radiat. Phys. Chem. 2003, 68, 387-394. [CrossRef]

17. Bhattacharya, A.; De, A. Conducting composites of polypyrrole and polyaniline a review. In Progress in Solid State Chemistry; Elsevier Ltd.: Amsterdam, The Netherlands, 1996; Volume 24, pp. 141-181. [CrossRef]

18. Kaur, G.; Adhikari, R.; Cass, P.; Bown, M.; Gunatillake, P. Electrically conductive polymers and composites for biomedical applications. RSC Adv. 2015, 5, 37553-37567. [CrossRef]

19. Oh, W.-K.; Kwon, O.S.; Jang, J. Conducting Polymer Nanomaterials for Biomedical Applications: Cellular Interfacing and Biosensing. Polym. Rev. 2013, 53, 407-442. [CrossRef]

20. Nezakati, T.; Seifalian, A.; Tan, A.; Seifalian, A.M. Conductive Polymers: Opportunities and Challenges in Biomedical Applications. Chem. Rev. 2018, 118, 6766-6843. [CrossRef]

21. Balint, R.; Cassidy, N.J.; Cartmell, S.H. Conductive polymers: Towards a smart biomaterial for tissue engineering. Acta Biomater. 2014, 10, 2341-2353. [CrossRef]

22. Ibanez, J.G.; Rincón, M.E.; Gutierrez-Granados, S.; Chahma, M.; Jaramillo-Quintero, O.A.; Frontana-Uribe, B.A. Conducting Polymers in the Fields of Energy, Environmental Remediation, and Chemical-Chiral Sensors. Chem. Rev. 2018, 118, 4731-4816. [CrossRef]

23. Taghizadeh, A.; Taghizadeh, M.; Jouyandeh, M.; Yazdi, M.K.; Zarintaj, P.; Saeb, M.R.; Lima, E.C.; Gupta, V.K. Conductive polymers in water treatment: A review. J. Mol. Liq. 2020, 312, 113447. [CrossRef]

24. Kang, E.-T. Polyaniline: A polymer with many interesting intrinsic redox states. Prog. Polym. Sci. 1998, 23, 277-324. [CrossRef]

25. Zare, E.N.; Motahari, A.; Sillanpää, M. Nanoadsorbents based on conducting polymer nanocomposites with main focus on polyaniline and its derivatives for removal of heavy metal ions/dyes: A review. Environ. Res. 2018, 162, 173-195. [CrossRef] [PubMed]

26. Shao, D.; Chen, C.; Wang, X. Application of polyaniline and multiwalled carbon nanotube magnetic composites for removal of Pb (II). Chem. Eng. J. 2012, 185-186, 144-150. [CrossRef]

27. Kumar, P.A.; Chakraborty, S.; Ray, M. Removal and recovery of chromium from wastewater using short chain polyaniline synthesized on jute fiber. Chem. Eng. J. 2008, 141, 130-140. [CrossRef]

28. Ren, J.; Huang, X.; Wang, N.; Lu, K.; Zhang, X.; Li, W.; Liu, D. Preparation of polyaniline-coated polyacrylonitrile fiber mats and their application to Cr (VI) removal. Synth. Met. 2016, 222, 255-266. [CrossRef]

29. Qiu, B.; Xu, C.; Sun, D.; Wang, Q.; Gu, H.; Zhang, X.; Weeks, B.L.; Hopper, J.; Ho, T.C.; Guo, Z.; et al. Polyaniline coating with various substrates for hexavalent chromium removal. Appl. Surf. Sci. 2015, 334, 7-14. [CrossRef]

30. Jiang, Y.; Liu, Z.; Zeng, G.; Liu, Y.; Shao, B.; Li, Z.; Liu, Y.; Zhang, W.; He, Q. Polyaniline-based adsorbents for removal of hexavalent chromium from aqueous solution: A mini review. Environ. Sci. Pollut. Res. 2018, 25, 6158-6174. [CrossRef] [PubMed]

31. Karthik, R.; Meenakshi, S. Removal of Cr (VI) ions by adsorption onto sodium alginate-polyaniline nanofibers. Int. J. Biol. Macromol. 2015, 72, 711-717. [CrossRef]

32. Ghorbani, M.; Lashkenari, M.S.; Eisazadeh, H. Application of polyaniline nanocomposite coated on rice husk ash for removal of $\mathrm{Hg}$ (II) from aqueous media. Synth. Met. 2011, 161, 1430-1433. [CrossRef]

33. Li, Q.; Yu, H.; Song, J.; Pan, X.; Liu, J.; Wang, Y.; Tang, L. Synthesis of SBA-15/polyaniline mesoporous composite for removal of resorcinol from aqueous solution. Appl. Surf. Sci. 2014, 290, 260-266. [CrossRef]

34. Jiang, N.; Xu, Y.; Dai, Y.; Luo, W.; Dai, L. Polyaniline nanofibers assembled on alginate microsphere for Cu2+ and Pb2+ uptake. J. Hazard. Mater. 2012, 215, 17-24. [CrossRef] [PubMed]

35. Mansour, M.; Ossman, M.; Farag, H. Removal of Cd (II) ion from waste water by adsorption onto polyaniline coated on sawdust. Desalination 2011, 272, 301-305. [CrossRef]

36. Karthik, R.; Meenakshi, S. Removal of $\mathrm{Pb}$ (II) and Cd (II) ions from aqueous solution using polyaniline grafted chitosan. Chem. Eng. J. 2015, 263, 168-177. [CrossRef]

37. Soltani, H.; Belmokhtar, A.; Zeggai, F.Z.; Benyoucef, A.; Bousalem, S.; Bachari, K. Copper (II) Removal from Aqueous Solutions by PANI-Clay Hybrid Material: Fabrication, Characterization, Adsorption and Kinetics Study. J. Inorg. Organomet. Polym. Mater. 2019, 29, 841-850. [CrossRef]

38. Nodeh, M.K.M.; Gabris, M.A.; Nodeh, H.R.; Bidhendi, M.E. Efficient removal of arsenic (III) from aqueous media using magnetic polyaniline-doped strontium-titanium nanocomposite. Environ. Sci. Pollut. Res. 2018, 25, 16864-16874. [CrossRef] [PubMed]

39. Madi, N.K.; Bhadra, J.; Al-Thani, N.J.; Alashraf, A.; Abdulmalik, D.; Al-Qaradawi, I. Adsorption study of Pb (II) in aqueous medium using polyaniline nanocomposites. J. Vinyl Addit. Technol. 2017, 23, E99-E106. [CrossRef] 
40. Yavuz, A.G.; Dincturk-Atalay, E.; Uygun, A.; Gode, F.; Aslan, E. A comparison study of adsorption of Cr (VI) from aqueous solutions onto alkyl-substituted polyaniline/chitosan composites. Desalination 2011, 279, 325-331. [CrossRef]

41. Jahan, K.; Kumar, N.; Verma, V. Removal of hexavalent chromium from potable drinking using a polyaniline-coated bacterial cellulose mat. Environ. Sci. Water Res. Technol. 2018, 4, 1589-1603. [CrossRef]

42. Ben Ali, M.; Wang, F.; Boukherroub, R.; Lei, W.; Xia, M. Phytic acid-doped polyaniline nanofibers-clay mineral for efficient adsorption of copper (II) ions. J. Colloid Interface Sci. 2019, 553, 688-698. [CrossRef]

43. Dognani, G.; Hadi, P.; Ma, H.; Cabrera, F.C.; Job, A.; Agostini, D.L.; Hsiao, B.S. Effective chromium removal from water by polyaniline-coated electrospun adsorbent membrane. Chem. Eng. J. 2019, 372, 341-351. [CrossRef]

44. Harijan, D.K.; Chandra, V. Polyaniline functionalized graphene sheets for treatment of toxic hexavalent chromium. J. Environ. Chem. Eng. 2016, 4, 3006-3012. [CrossRef]

45. Ayad, M.; El-Hefnawy, G.; Zaghlol, S. Facile synthesis of polyaniline nanoparticles; its adsorption behavior. Chem. Eng. J. 2013, 217, 460-465. [CrossRef]

46. Janaki, V.; Vijayaraghavan, K.; Oh, B.-T.; Lee, K.-J.; Muthuchelian, K.; Ramasamy, A.; Kamala-Kannan, S. Starch/polyaniline nanocomposite for enhanced removal of reactive dyes from synthetic effluent. Carbohydr. Polym. 2012, 90, 1437-1444. [CrossRef] [PubMed]

47. Chowdhury, A.-N.; Jesmeen, S.R.; Hossain, M.M. Removal of dyes from water by conducting polymeric adsorbent. Polym. Adv. Technol. 2004, 15, 633-638. [CrossRef]

48. Shen, J.; Shahid, S.; Amura, I.; Sarihan, A.; Tian, M.; Emanuelsson, E.A. Enhanced adsorption of cationic and anionic dyes from aqueous solutions by polyacid doped polyaniline. Synth. Met. 2018, 245, 151-159. [CrossRef]

49. Sharma, V.; Rekha, P.; Mohanty, P. Nanoporous hypercrosslinked polyaniline: An efficient adsorbent for the adsorptive removal of cationic and anionic dyes. J. Mol. Liq. 2016, 222, 1091-1100. [CrossRef]

50. Khan, N.A.; An, H.J.; Yoo, D.K.; Jhung, S.H. Polyaniline-derived porous carbons: Remarkable adsorbent for removal of various hazardous organics from both aqueous and non-aqueous media. J. Hazard. Mater. 2018, 360, 163-171. [CrossRef] [PubMed]

51. Gupta, V.K.; Pathania, D.; Kothiyal, N.; Sharma, G. Polyaniline zirconium (IV) silicophosphate nanocomposite for remediation of methylene blue dye from waste water. J. Mol. Liq. 2014, 190, 139-145. [CrossRef]

52. Zhao, Y.; Chen, H.; Li, J.; Chen, C. Hierarchical MWCNTs $/ \mathrm{Fe}_{3} \mathrm{O}_{4} /$ PANI magnetic composite as adsorbent for methyl orange removal. J. Colloid Interface Sci. 2015, 450, 189-195. [CrossRef]

53. Janaki, V.; Oh, B.-T.; Vijayaraghavan, K.; Kim, J.-W.; Kim, S.A.; Ramasamy, A.; Kamala-Kannan, S. Application of bacterial extracellular polysaccharides/polyaniline composite for the treatment of Remazol effluent. Carbohydr. Polym. 2012, 88, 1002-1008. [CrossRef]

54. Salem, M.A.; Elsharkawy, R.G.; Hablas, M.F. Adsorption of brilliant green dye by polyaniline/silver nanocomposite: Kinetic, equilibrium, and thermodynamic studies. Eur. Polym. J. 2016, 75, 577-590. [CrossRef]

55. Muhammad, A.; Shah, A.-U.-H.A.; Bilal, S.; Rahman, G. Basic Blue Dye Adsorption from Water Using Polyaniline/Magnetite $\left(\mathrm{Fe}_{3} \mathrm{O}_{4}\right)$ Composites: Kinetic and Thermodynamic Aspects. Materials 2019, 12, 1764. [CrossRef]

56. Anirudhan, T.S.; Divya, P.L.; Nima, J. Utilization of polypyrrole coated iron-doped titania based hydrogel for the removal of tetracycline hydrochloride from aqueous solutions: Adsorption and photocatalytic degradation studies. Environ. Nanotechnol. Monit. Manag. 2015, 4, 106-117. [CrossRef]

57. Nasar, A.; Mashkoor, F. Application of polyaniline-based adsorbents for dye removal from water and wastewater-A review. Environ. Sci. Pollut. Res. 2019, 26, 5333-5356. [CrossRef]

58. Sultana, S.; Rafiuddin; Khan, M.Z.; Umar, K.; Muneer, M. Electrical, Thermal, Photocatalytic and Antibacterial Studies of Metallic Oxide Nanocomposite Doped Polyaniline. J. Mater. Sci. Technol. 2013, 29, 795-800. [CrossRef]

59. Allahveran, S.; Mehrizad, A. Polyaniline/ZnS nanocomposite as a novel photocatalyst for removal of Rhodamine 6G from aqueous media: Optimization of influential parameters by response surface methodology and kinetic modeling. J. Mol. Liq. 2017, 225, 339-346. [CrossRef]

60. Eskizeybek, V.; Sari, F.; Gülce, H.; Gülce, A.; Avc1, A. Preparation of the new polyaniline/ZnO nanocomposite and its photocatalytic activity for degradation of methylene blue and malachite green dyes under UV and natural sun lights irradiations. Appl. Catal. B Environ. 2012, 119-120, 197-206. [CrossRef]

61. Agarwal, S.; Tyagi, I.; Gupta, V.K.; Golbaz, F.; Golikand, A.N.; Moradi, O. Synthesis and characteristics of polyaniline/zirconium oxide conductive nanocomposite for dye adsorption application. J. Mol. Liq. 2016, 218, 494-498. [CrossRef]

62. Pathania, D.; Sharma, G.; Kumar, A.; Kothiyal, N.C. Fabrication of nanocomposite polyaniline zirconium (IV) silicophosphate for photocatalytic and antimicrobial activity. J. Alloys Compd. 2014, 588, 668-675. [CrossRef]

63. Sun, C.; Xiong, B.; Pan, Y.; Cui, H. Adsorption removal of tannic acid from aqueous solution by polyaniline: Analysis of operating parameters and mechanism. J. Colloid Interface Sci. 2017, 487, 175-181. [CrossRef] [PubMed]

64. Hasan, M.; Rashid, M.; Hossain, M.M.; Al Mesfer, M.K.; Arshad, M.; Danish, M.; Lee, M.; El Jery, A.; Kumar, N. Fabrication of polyaniline/activated carbon composite and its testing for methyl orange removal: Optimization, equilibrium, isotherm and kinetic study. Polym. Test. 2019, 77, 105909. [CrossRef]

65. Gopal, N.; Asaithambi, M.; Sivakumar, P. Adsorption studies of a direct dye using polyaniline coated activated carbon prepared from Prosopis juliflora. J. Water Process. Eng. 2014, 2, 87-95. [CrossRef] 
66. Kanwal, F.; Rehman, R.; Bakhsh, I.Q. Batch wise sorptive amputation of diamond green dye from aqueous medium by novel Polyaniline-Alstonia scholaris leaves composite in ecofriendly way. J. Clean. Prod. 2018, 196, 350-357. [CrossRef]

67. Janaki, V.; Oh, B.-T.; Shanthi, K.; Lee, K.-J.; Ramasamy, A.; Kamala-Kannan, S. Polyaniline/chitosan composite: An eco-friendly polymer for enhanced removal of dyes from aqueous solution. Synth. Met. 2012, 162, 974-980. [CrossRef]

68. Mu, B.; Tang, J.; Zhang, L.; Wang, A. Preparation, characterization and application on dye adsorption of a well-defined twodimensional superparamagnetic clay/polyaniline/ $\mathrm{Fe}_{3} \mathrm{O}_{4}$ nanocomposite. Appl. Clay Sci. 2016, 132, 7-16. [CrossRef]

69. Zaremotlagh, S.; Hezarkhani, A. Removal of textile dyes from aqueous solution by conducting polymer modified clinoptilolite. Environ. Earth Sci. 2013, 71, 2999-3006. [CrossRef]

70. Muhammad, A.; Bilal, S. Comparative Study of the Adsorption of Acid Blue 40 on Polyaniline, Magnetic Oxide and Their Composites: Synthesis, Characterization and Application. Materials 2019, 12, 2854. [CrossRef]

71. Mahto, T.K.; Chowdhuri, A.R.; Sahu, S.K. Polyaniline-functionalized magnetic nanoparticles for the removal of toxic dye from wastewater. J. Appl. Polym. Sci. 2014, 131, 40840. [CrossRef]

72. Yan, B.; Chen, Z.; Cai, L.; Chen, Z.; Fu, J.; Xu, Q. Fabrication of polyaniline hydrogel: Synthesis, characterization and adsorption of methylene blue. Appl. Surf. Sci. 2015, 356, 39-47. [CrossRef]

73. Ballav, N.; Debnath, S.; Pillay, K.; Maity, A. Efficient removal of Reactive Black from aqueous solution using polyaniline coated ligno-cellulose composite as a potential adsorbent. J. Mol. Liq. 2015, 209, 387-396. [CrossRef]

74. Debnath, S.; Ballav, N.; Maity, A.; Pillay, K. Development of a polyaniline-lignocellulose composite for optimal adsorption of Congo red. Int. J. Biol. Macromol. 2015, 75, 199-209. [CrossRef]

75. Lyu, W.; Yu, M.; Feng, J.; Yan, W. Highly crystalline polyaniline nanofibers coating with low-cost biomass for easy separation and high efficient removal of anionic dye ARG from aqueous solution. Appl. Surf. Sci. 2018, 458, 413-424. [CrossRef]

76. Bhaumik, M.; McCrindle, R.I.; Maity, A.; Agarwal, S.; Gupta, V.K. Polyaniline nanofibers as highly effective re-usable adsorbent for removal of reactive black 5 from aqueous solutions. J. Colloid Interface Sci. 2016, 466, 442-451. [CrossRef]

77. Patil, M.R.; Shrivastava, V.S. Adsorption of malachite green by polyaniline-nickel ferrite magnetic nanocomposite: An isotherm and kinetic study. Appl. Nanosci. 2014, 5, 809-816. [CrossRef]

78. Liang, Y.-D.; He, Y.-J.; Zhang, Y.-H.; Zhu, Q.-Q. Adsorption property of alizarin red $\mathrm{S}$ by $\mathrm{NiFe}_{2} \mathrm{O}_{4}$ / polyaniline magnetic composite. J. Environ. Chem. Eng. 2018, 6, 416-425. [CrossRef]

79. Zarrini, K.; Rahimi, A.A.; Alihosseini, F.; Fashandi, H. Highly efficient dye adsorbent based on polyaniline-coated nylon-6 nanofibers. J. Clean. Prod. 2017, 142, 3645-3654. [CrossRef]

80. Rachna, K.; Agarwal, A.; Singh, N. Preparation and characterization of zinc ferrite-Polyaniline nanocomposite for removal of rhodamine B dye from aqueous solution. Environ. Nanotechnol. Monit. Manag. 2018, 9, 154-163. [CrossRef]

81. Li, X.; Sui, Z.Y.; Sun, Y.N.; Xiao, P.W.; Wang, X.Y.; Han, B.H. Polyaniline-derived hierarchically porous nitrogen-doped carbons as gas adsorbents for carbon dioxide uptake. Microporous Mesoporous Mater. 2018, 257, 85-91. [CrossRef]

82. Yang, S.-B. Removal of ammonia gas via conducting polymer-assisted titania under visible light or UV exposure. Asian J. Chem. 2014, 26, 70-73. [CrossRef]

83. Hursán, D.; Kormányos, A.; Rajeshwar, K.; Janáky, C. Polyaniline films photoelectrochemically reduce $\mathrm{CO}_{2}$ to alcohols. Chem. Commun. 2016, 52, 8858-8861. [CrossRef]

84. Della Pina, C.; De Gregorio, M.A.; Clerici, L.; Dellavedova, P.; Falletta, E. Polyaniline (PANI): An innovative support for sampling and removal of VOCs in air matrices. J. Hazard. Mater. 2018, 344, 308-315. [CrossRef] [PubMed]

85. Zhang, S.; Gao, L.; Shan, L.; Wang, R.; Min, Y. Comparative Study on the Adsorption of NO2 Using Different Clay/Polyaniline Composites. Ind. Eng. Chem. Res. 2018, 57, 6897-6903. [CrossRef]

86. Saad, M.; Tahir, H.; Khan, J.; Hameed, U.; Saud, A. Synthesis of polyaniline nanoparticles and their application for the removal of Crystal Violet dye by ultrasonicated adsorption process based on Response Surface Methodology. Ultrason. Sonochem. 2017, 34, 600-608. [CrossRef]

87. Lyu, W.; Wu, J.; Zhang, W.; Liu, Y.; Yu, M.; Zhao, Y.; Feng, J.; Yan, W. Easy separated 3D hierarchical coral-like magnetic polyaniline adsorbent with enhanced performance in adsorption and reduction of $\mathrm{Cr}$ (VI) and immobilization of $\mathrm{Cr}$ (III). Chem. Eng. J. 2019, 363, 107-119. [CrossRef]

88. Aliabadi, R.S.; Mahmoodi, N.O. Synthesis and characterization of polypyrrole, polyaniline nanoparticles and their nanocomposite for removal of azo dyes; sunset yellow and Congo red. J. Clean. Prod. 2018, 179, 235-245. [CrossRef]

89. Tanzifi, M.; Yaraki, M.T.; Kiadehi, A.D.; Hosseini, S.H.; Olazar, M.; Bharti, A.K.; Agarwal, S.; Gupta, V.K.; Kazemi, A. Adsorption of Amido Black 10B from aqueous solution using polyaniline $/ \mathrm{SiO}_{2}$ nanocomposite: Experimental investigation and artificial neural network modeling. J. Colloid Interface Sci. 2018, 510, 246-261. [CrossRef]

90. Samani, M.R.; Borghei, S.M.; Olad, A.; Chaichi, M.J. Removal of chromium from aqueous solution using polyaniline-Poly ethylene glycol composite. J. Hazard. Mater. 2010, 184, 248-254. [CrossRef] [PubMed]

91. Xia, Y.; Li, T.; Chen, J.; Cai, C. Polyaniline (skin)/polyamide 6 (core) composite fiber: Preparation, characterization and application as a dye adsorbent. Synth. Met. 2013, 175, 163-169. [CrossRef]

92. Wang, J.; Zhang, K.; Zhao, L. Sono-assisted synthesis of nanostructured polyaniline for adsorption of aqueous Cr (VI): Effect of protonic acids. Chem. Eng. J. 2014, 239, 123-131. [CrossRef]

93. Zeng, Y.; Zhao, L.; Wu, W.; Lu, G.; Xu, F.; Tong, Y.; Liu, W.; Du, J. Enhanced adsorption of malachite green onto carbon nanotube/polyaniline composites. J. Appl. Polym. Sci. 2013, 127, 2475-2482. [CrossRef] 
94. Setshedi, K.Z.; Bhaumik, M.; Songwane, S.; Onyango, M.S.; Maity, A. Exfoliated polypyrrole-organically modified montmorillonite clay nanocomposite as a potential adsorbent for Cr (VI) removal. Chem. Eng. J. 2013, 222, 186-197. [CrossRef]

95. Karthik, R.; Meenakshi, S. Synthesis, characterization and Cr (VI) uptake studies of polypyrrole functionalized chitin. Synth. Met. 2014, 198, 181-187. [CrossRef]

96. Bhaumik, M.; Agarwal, S.; Gupta, V.K.; Maity, A. Enhanced removal of Cr (VI) from aqueous solutions using polypyrrole wrapped oxidized MWCNTs nanocomposites adsorbent. J. Colloid Interface Sci. 2016, 470, 257-267. [CrossRef]

97. Amalraj, A.; Selvi, M.K.; Rajeswari, A.; Christy, E.J.S.; Pius, A. Efficient removal of toxic hexavalent chromium from aqueous solution using threonine doped polypyrrole nanocomposite. J. Water Process. Eng. 2016, 13, 88-99. [CrossRef]

98. Kera, N.H.; Bhaumik, M.; Ballav, N.; Pillay, K.; Ray, S.S.; Maity, A. Selective removal of Cr (VI) from aqueous solution by polypyrrole/2,5-diaminobenzene sulfonic acid composite. J. Colloid Interface Sci. 2016, 476, 144-157. [CrossRef] [PubMed]

99. Ballav, N.; Maity, A.; Mishra, S.B. High efficient removal of chromium (VI) using glycine doped polypyrrole adsorbent from aqueous solution. Chem. Eng. J. 2012, 198-199, 536-546. [CrossRef]

100. Abdi, S.; Nasiri, M.; Mesbahi, A.; Khani, M. Investigation of uranium (VI) adsorption by polypyrrole. J. Hazard. Mater. 2017, 332, 132-139. [CrossRef]

101. Hosseini, S.; Mahmud, N.E.; Yahya, R.B.; Ibrahim, F.; Djordjevic, I. Polypyrrole conducting polymer and its application in removal of copper ions from aqueous solution. Mater. Lett. 2015, 149, 77-80. [CrossRef]

102. Li, S.; Lu, X.; Li, X.; Xue, Y.; Zhang, C.; Lei, J.; Wang, C. Preparation of bamboo-like PPy nanotubes and their application for removal of $\mathrm{Cr}(\mathrm{VI})$ ions in aqueous solution. J. Colloid Interface Sci. 2012, 378, 30-35. [CrossRef] [PubMed]

103. Du, L.; Gao, P.; Meng, Y.; Liu, Y.; Le, S.; Yu, C. Highly Efficient Removal of Cr (VI) from Aqueous Solutions by Polypyrrole/Monodisperse Latex Spheres. ACS Omega 2020, 5, 6651-6660. [CrossRef]

104. Xu, Y.; Chen, J.; Chen, R.; Yu, P.; Guo, S.; Wang, X. Adsorption and reduction of chromium (VI) from aqueous solution using polypyrrole/calcium rectorite composite adsorbent. Water Res. 2019, 160, 148-157. [CrossRef] [PubMed]

105. Chávez-Guajardo, A.E.; Medina-Llamas, J.C.; Maqueira, L.; Andrade, C.A.; Alves, K.; de Melo, C.P. Efficient removal of Cr (VI) and $\mathrm{Cu}$ (II) ions from aqueous media by use of polypyrrole/maghemite and polyaniline/maghemite magnetic nanocomposites. Chem. Eng. J. 2015, 281, 826-836. [CrossRef]

106. Zhao, Y.; Xia, K.; Zhang, Z.; Zhu, Z.; Guo, Y.; Qu, Z. Facile Synthesis of Polypyrrole-Functionalized $\mathrm{CoFe}_{2} \mathrm{O}_{4} @ \mathrm{SiO}_{2}$ for Removal for $\mathrm{Hg}(\mathrm{II})$. Nanomaterials 2019, 9, 455. [CrossRef] [PubMed]

107. Alawa, B.; Srivstava, J.K.; Srivastava, A.; Palsania, J. Adsorption of Heavy Metal Pb (II) from Synthetic Waste Water by Polypyrrole composites. Int. J. Chem. Stud. 2015, 3, 4-8.

108. Falahian, Z.; Torki, F.; Faghihian, H. Synthesis and Application of Polypyrrole $/ \mathrm{Fe}_{3} \mathrm{O}_{4}$ Nanosize Magnetic Adsorbent for Efficient Separation of $\mathrm{Hg}_{2+}$ from Aqueous Solution. Glob. Chall. 2018, 2, 1700078. [CrossRef]

109. Tanzifi, M.; Nezhad, M.K.; Karimipour, K. Kinetic and Isotherm Studies of Cadmium Adsorption on Polypyrrole/Titanium dioxide Nanocomposite. J. Water Environ. Nanotechnol. 2017, 2, 265-277.

110. Maity, S.; Dubey, A.; Chakraborty, S. A review on polypyrrole-coated bio-composites for the removal of heavy metal traces from waste water. J. Ind. Text. 2021, 51, 152-173. [CrossRef]

111. Sathe, S.; Chakraborty, I.; Dubey, B.; Ghangrekar, M. Microbial fuel cell coupled Fenton oxidation for the cathodic degradation of emerging contaminants from wastewater: Applications and challenges. Environ. Res. 2022, 204, 112135. [CrossRef] [PubMed]

112. Olatunji, M.A.; Khandaker, M.U.; Amin, Y.M.; Mahmud, H.N.M.E. Cadmium-109 Radioisotope Adsorption onto Polypyrrole Coated Sawdust of Dryobalanops aromatic: Kinetics and Adsorption Isotherms Modelling. PLoS ONE 2016, 11, e0164119. [CrossRef]

113. Eisazadeh, H.; Engineering, C.; Box, P.O. Removal of Arsenic in Water Using Polypyrrole and its Composites. Methods 2008, 3 , 10-13.

114. Zhou, T.; Liang, Q.; Zhou, X.; Luo, H.; Chen, W. Enhanced removal of toxic hexavalent chromium from aqueous solution by magnetic Zr-MOF@polypyrrole: Performance and mechanism. Environ. Sci. Pollut. Res. 2021, 28, 13084-13096. [CrossRef] [PubMed]

115. Bhaumik, M.; Maity, A.; Srinivasu, V.; Onyango, M.S. Removal of hexavalent chromium from aqueous solution using polypyrrolepolyaniline nanofibers. Chem. Eng. J. 2012, 181-182, 323-333. [CrossRef]

116. Islam, M.; Mishra, S.; Swain, S.K.; Patel, R.; Dey, R.K.; Naushad, M. Evaluation of Phosphate Removal Efficiency from Aqueous Solution by Polypyrrole/BOF Slag Nanocomposite. Sep. Sci. Technol. 2014, 49, 2668-2680. [CrossRef]

117. Fang, W.; Jiang, X.; Luo, H.; Geng, J. Synthesis of graphene $/ \mathrm{SiO}_{2} @$ polypyrrole nanocomposites and their application for Cr (VI) removal in aqueous solution. Chemosphere 2018, 197, 594-602. [CrossRef]

118. Fan, L.; Wei, C.; Xu, Q.; Xu, J. Polypyrrole-coated cotton fabrics used for removal of methylene blue from aqueous solution. J. Text. Inst. 2017, 108, 1847-1852. [CrossRef]

119. Li, J.; Feng, J.; Yan, W. Excellent adsorption and desorption characteristics of polypyrrole/ $\mathrm{TiO}_{2}$ composite for Methylene Blue. Appl. Surf. Sci. 2013, 279, 400-408. [CrossRef]

120. Chen, Y.; Lin, Z.; Hao, R.; Xu, H.; Huang, C. Rapid adsorption and reductive degradation of Naphthol Green B from aqueous solution by Polypyrrole/Attapulgite composites supported nanoscale zero-valent iron. J. Hazard. Mater. 2019, 371, 8-17. [CrossRef] 
121. Zhou, J.; Lü, Q.F.; Luo, J.J. Efficient removal of organic dyes from aqueous solution by rapid adsorption onto polypyrrole-based composites. J. Clean. Prod. 2017, 167, 739-748. [CrossRef]

122. Boukoussa, B.; Hakiki, A.; Moulai, S.; Chikh, K.; Kherroub, D.E.; Bouhadjar, L.; Guedal, D.; Messaoudi, K.; Mokhtar, F.; Hamacha, R. Adsorption behaviors of cationic and anionic dyes from aqueous solution on nanocomposite polypyrrole/SBA-15. J. Mater. Sci. 2018, 53, 7372-7386. [CrossRef]

123. Yang, B.Y.; Cao, Y.; Qi, F.F.; Li, X.Q.; Xu, Q. Atrazine adsorption removal with nylon6/polypyrrole core-shell nanofibers mat: Possible mechanism and characteristics. Nanoscale Res. Lett. 2015, 10, 207. [CrossRef] [PubMed]

124. Palanisamy, P.N.; Agalya, A.; Sivakumar, P. Polypyrrole Composite-A Potential Material for the Removal of Acid Dyes. Asian J. Chem. 2013, 25, 5891-5896. [CrossRef]

125. Feng, J.; Li, J.; Lv, W.; Xu, H.; Yang, H.; Yan, W. Synthesis of polypyrrole nano-fibers with hierarchical structure and its adsorption property of Acid Red G from aqueous solution. Synth. Met. 2014, 191, 66-73. [CrossRef]

126. Pires, B.C.; Nascimento, T.A.D.; Dutra, F.V.A.; Borges, K.B. Removal of a non-steroidal anti-inflammatory by adsorption on polypyrrole/multiwalled carbon nanotube composite-Study of kinetics and equilibrium in aqueous medium. Colloids Surf. A Physicochem. Eng. Asp. 2019, 578, 123583. [CrossRef]

127. Duan, W.; Li, M.; Xiao, W.; Wang, N.; Niu, B.; Zhou, L.; Zheng, Y. Enhanced adsorption of three fluoroquinolone antibiotics using polypyrrole functionalized Calotropis gigantea fiber. Colloids Surf. A Physicochem. Eng. Asp. 2019, 574, 178-187. [CrossRef]

128. Yağmur, H.K. Synthesis and characterization of conducting polypyrrole/bentonite nanocomposites and in-situ oxidative polymerization of pyrrole: Adsorption of 4-nitrophenol by polypyrrole/bentonite nanocomposite. Chem. Eng. Commun. 2020, 207, 1171-1183. [CrossRef]

129. Laabd, M.; El Jaouhari, A.; Haki, M.A.; Eljazouli, H.; Bazzaoui, M.; Kabli, H.; Albourine, A. Simultaneous removal of benzene polycarboxylic acids from water by polypyrrole composite filled with a cellulosic agricultural waste. J. Environ. Chem. Eng. 2016, 4, 1869-1879. [CrossRef]

130. Stejskal, J. Interaction of conducting polymers, polyaniline and polypyrrole, with organic dyes: Polymer morphology control, dye adsorption and photocatalytic decomposition. Chem. Pap. 2019, 74, 1-54. [CrossRef]

131. Bhaumik, M.; McCrindle, R.; Maity, A. Efficient removal of Congo red from aqueous solutions by adsorption onto interconnected polypyrrole-polyaniline nanofibres. Chem. Eng. J. 2013, 228, 506-515. [CrossRef]

132. Ovando-Medina, V.M.; Vizcaíno-Mercado, J.; Gonzalez-Ortega, O.; De La Garza, J.A.R.; Martínez-Gutiérrez, H. Synthesis of $\alpha$-cellulose/polypyrrole composite for the removal of reactive red dye from aqueous solution: Kinetics and equilibrium modeling. Polym. Compos. 2014, 36, 312-321. [CrossRef]

133. Ayad, M.; Salahuddin, N.; Fayed, A.; Bastakoti, B.P.; Suzuki, N.; Yamauchi, Y. Chemical design of a smart chitosan-polypyrrolemagnetite nanocomposite toward efficient water treatment. Phys. Chem. Chem. Phys. 2014, 16, 21812-21819. [CrossRef]

134. Ayad, M.M.; Amer, W.; Zaghlol, S.; Minisy, I.; Bober, P.; Stejskal, J. Polypyrrole-coated cotton textile as adsorbent of methylene blue dye. Chem. Pap. 2018, 72, 1605-1618. [CrossRef]

135. Ansari, R.R.; Mosayebzadeh, Z. Removal of basic dye methylene blue from aqueous solutions using sawdust and sawdust coated with polypyrrole. J. Iran. Chem. Soc. 2010, 7, 339-350. [CrossRef]

136. Adhikari, A.; De, S.; Halder, A.; Pattanayak, S.; Dutta, K.; Mondal, D.; Rana, D.; Ghosh, R.; Bera, N.K.; Chattopadhyay, S.; et al. Biosurfactant tailored synthesis of porous polypyrrole nanostructures: A facile approach towards $\mathrm{CO} 2$ adsorption and dopamine sensing. Synth. Met. 2018, 245, 209-222. [CrossRef]

137. Hussein, M.A. Eco-Friendly Polythiophene(keto-amine)s Based on Cyclopentanone Moiety for Environmental Remediation. J. Polym. Environ. 2018, 26, 1194-1205. [CrossRef]

138. Mishra, A.K.; Agrawal, N.R.; Das, I. Synthesis of water dispersible dendritic amino acid modified polythiophenes as highly effective adsorbent for removal of methylene blue. J. Environ. Chem. Eng. 2017, 5, 4923-4936. [CrossRef]

139. Kharazi, P.; Rahimi, R.; Rabbani, M. Study on porphyrin $/ \mathrm{ZnFe}_{2} \mathrm{O}_{4} @$ polythiophene nanocomposite as a novel adsorbent and visible light driven photocatalyst for the removal of methylene blue and methyl orange. Mater. Res. Bull. 2018, 103, 133-141. [CrossRef]

140. Faisal, M.; Harraz, F.A.; Ismail, A.A.; El-Toni, A.M.; Al-Sayari, S.; Al-Hajry, A.; Al-Assiri, M.S. Polythiophene/mesoporous SrTiO 3 nanocomposites with enhanced photocatalytic activity under visible light. Sep. Purif. Technol. 2018, 190, 33-44. [CrossRef]

141. Ansari, R.; Feizy, J.; Delavar, A.F. Removal of Arsenic Ions from Aqueous Solutions Using Conducting Polymers. Eur. J. Adv. Chem. Res. 2008, 5, 853-863. [CrossRef]

142. Zoleikani, L.; Issazadeh, H.; ZareNezhad, B. Preparation of new conductive polymer nanocomposites for cadmium removal from industrial wastewaters. J. Chem. Technol. Metall. 2015, 50, 71-80.

143. Din, M.I.; Ata, S.; Mohsin, I.U.; Rasool, A.; Aziz, A.A. Evaluation of conductive polymers as an adsorbent for eradication of As (III) from aqueous solution using inductively coupled plasma optical emission spectroscopy (ICP-OES). Int. J. Sci. Eng. 2014, 6, 154-162. [CrossRef]

144. Javadian, H. Application of kinetic, isotherm and thermodynamic models for the adsorption of Co (II) ions on polyaniline/polypyrrole copolymer nanofibers from aqueous solution. J. Ind. Eng. Chem. 2014, 20, 4233-4241. [CrossRef]

145. Haki, M.A.; Laabd, M.; Chafai, H.; Kabli, H.; Ez-Zahery, M.; Bazzaoui, M.; Lakhmiri, R.; Albourine, A. Comparative adsorption of nitrate ions on the polypyrrole and polyaniline from aqueous solution. J. Dispers. Sci. Technol. 2016, 38, 598-603. [CrossRef] 
146. Chafai, H.; Laabd, M.; Elbariji, S.; Bazzaoui, M.; Albourine, A. Study of congo red adsorption on the polyaniline and polypyrrole. J. Dispers. Sci. Technol. 2016, 38, 832-836. [CrossRef]

147. Maruthapandi, M.; Kumar, V.B.; Luong, J.H.T.; Gedanken, A. Kinetics, Isotherm, and Thermodynamic Studies of Methylene Blue Adsorption on Polyaniline and Polypyrrole Macro-Nanoparticles Synthesized by C-Dot-Initiated Polymerization. ACS Omega 2018, 3, 7196-7203. [CrossRef]

148. Chigondo, M.; Paumo, H.K.; Bhaumik, M.; Pillay, K.; Maity, A. Magnetic arginine-functionalized polypyrrole with improved and selective chromium (VI) ions removal from water. J. Mol. Liq. 2019, 275, 778-791. [CrossRef]

149. Wang, H.; Yuan, X.; Wu, Y.; Chen, X.; Leng, L.; Wang, H.; Li, H.; Zeng, G. Facile synthesis of polypyrrole decorated reduced graphene oxide- $\mathrm{Fe}_{3} \mathrm{O}_{4}$ magnetic composites and its application for the $\mathrm{Cr}$ (VI) removal. Chem. Eng. J. 2015, 262, 597-606. [CrossRef]

150. Shao, Y.; Fan, Z.; Zhong, M.; Xu, W.; He, C.; Zhang, Z. Polypyrrole/bacterial cellulose nanofiber composites for hexavalent chromium removal. Cellulose 2021, 28, 2229-2240. [CrossRef]

151. Liu, W.; Yang, L.; Xu, S.; Chen, Y.; Liu, B.; Li, Z.; Jiang, C. Efficient removal of hexavalent chromium from water by an adsorption-reduction mechanism with sandwiched nanocomposites. RSC Adv. 2018, 8, 15087-15093. [CrossRef]

152. Deivanayaki, S.; Ponnuswamy, V.; Mariappan, R.; Jayamurugan, P. Synthesis and characterization of polypyrrole/TiO2 composites by chemical oxidative method. Optik (Stuttg) 2013, 124, 1089-1091. [CrossRef]

153. Yang, Y.; Chen, N.; Feng, C.; Li, M.; Gao, Y. Chromium removal using a magnetic corncob biochar/polypyrrole composite by adsorption combined with reduction: Reaction pathway and contribution degree. Colloids Surf. A Physicochem. Eng. Asp. 2018, 556, 201-209. [CrossRef]

154. Feng, J.; Sun, N.; Wu, D.; Yang, H.; Xu, H.; Yan, W. Preparation of $\mathrm{Fe}_{3} \mathrm{O}_{4} / \mathrm{TiO}_{2} /$ Polypyrrole Ternary Magnetic Composite and Using as Adsorbent for the Removal of Acid Red G. J. Polym. Environ. 2016, 25, 781-791. [CrossRef] 